\title{
Characteristics of Baseline and Analysis of Pollution on the Heavy Metals in Surficial Soil of Guiyang
}

\author{
Ji Wang 1,2 and Yixiu Zhang1,2 \\ ${ }^{1}$ School of Geographical and Environment Sciences \\ Guizhou Normal University, Guiyang, Guizhou \\ ${ }^{2}$ Key Laboratory of Remote Sensing Applications in Resources and Environments, Guizhou
}

China

\section{Introduction}

The term "Environmental Geochemical Baseline (EGB)" first appeared in the International Geochemical Mapping Program (IGCP259) and the International Geochemical Baseline Program (IGCP360) of International Geo-graph Contrast Program. The definition of EGB refers to natural changes in the concentrations of chemical materials (chemical elements) in the Earth's surface material (Salminen \&Tarvainen, 1997). But the definition is becoming clearer with deepening research on EGB. The geochemical baseline reflects the natural concentration of one element in a particular material (e.g. soil, sediment, and rock). At the same time, it can be described as the unitary limit to distinguish the geochemistry backgrounds and anomalies (Salminen \& Gregorau-skiene, 2000).

As for the EGB, it is required to establish the archives of the current Earth's surface environment and provide the database to monitor environmental variation. The aim of EGB is to reveal natural changes in mineral and chemical elements so as to make comparisons with anthropogenic influences. The EGB provides the definition of geochemical variation in natural space. It can not only guider policy-makers to make policies toward environmental problems, but also can educate the public who are interested in environmental problems (Darnley, 1997).

All countries attach great importance to the study of EGB, e.g. Mapping of EGB in Europe (Darnley, 1997). For coping with the world EGB studies, China kicked off the program of "Chinese Environment Geochemistry Supervision and Control Network, and the National Dynamic Mapping of Geochemistry Items" in 1992(Chen Hangxin et al., 1998). Use of the EGB to study the environment impact of mining and smelting activities was carried out in the region of Panzhihua, Sichuan Province, Southwest China (Teng Yanguo et al., 2002, 2003).

In this chapter there has been established the surficial soil EGB of heavy metals $(\mathrm{Hg}, \mathrm{Cd}, \mathrm{As}$, $\mathrm{Pb}, \mathrm{Cr}, \mathrm{Cu}, \mathrm{Ni}$ and $\mathrm{Zn}$ ) in Guiyang City(covering an area of $8046 \mathrm{~km}^{2}$ ), Guizhou Province. With soil environmental geochemistry research as the main line the spatial distribution of the heavy metals in surficial soil is combined with research on environmentally geochemical mechanism. An appropriate guideline is chosen to distinguish the influence of natural processes from that of anthropogenic processes on soil environment. 


\section{Materials and methods}

\subsection{Study area}

Guiyang City was selected as the study area which is the capital of Guizhou Province in Southwest China. Guiyang City, situated between east longitude $106^{\circ} 07^{\prime}$ to $107^{\circ} 17^{\prime}$, north latitude $26^{\circ} 11^{\prime}$ to $27^{\circ} 22^{\prime}$, lies in the middle of Guizhou Province and on the eastern slope of YunnanGuizhou Plateau (Fig.1). Guiyang, with abundant natural resources, ample energy resources and good natural environment, has a mild-moist subtropical climate because of diversity in geographical and topomorphic features, high elevation and low latitude. The total area of Guiyang was $8046 \mathrm{~km}^{2}$, including farmland $(35.91 \%)$, woodland $(33.09 \%)$, grassland $(3.59 \%)$, water area $(1.89 \%)$, construction land (e.g. residential area, industry, mining, transportation, et al.) $(6.00 \%)$, garden area $(0.70 \%)$ and no-use land $(18.82 \%)$ (e.g. wilderness, ribbing, lake-beach, et al.) according to the land use. Soils in the study area mainly include yellow soil $\left(3.335 \times 10^{5}\right.$ $\left.\mathrm{hm}^{2}, 41.53 \%\right)$, umber soil $(1.49 \%)$, limestone soil $\left(2.021 \times 105 \mathrm{hm}^{2}, 25.17 \%\right)$, rocky soil $(2.17 \%)$, coarse-bone soil $(12.64 \%)$, purple soil $(1.93 \%)$, marsh soil $(0.11 \%)$, paddy soil $\left(1.156 \times 10^{5} \mathrm{hm}^{2}\right.$, $14.39 \%$ ), and mountainous meadow soil (0.5\%) (Fig.2).

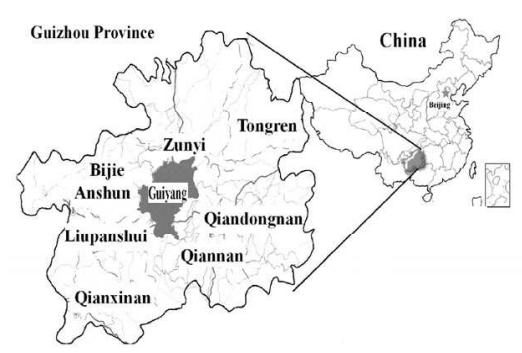

Fig. 1. Map showing the study site in Guizhou.

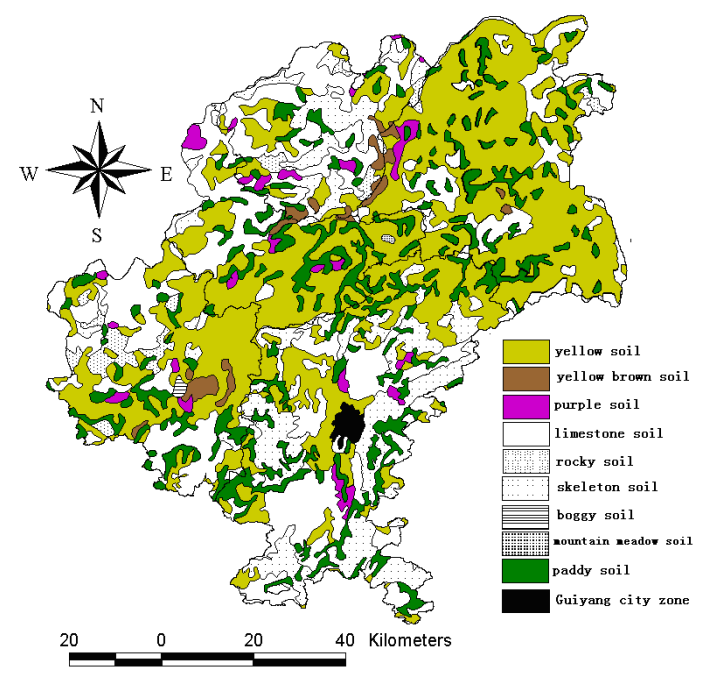

Fig. 2. The distribution of surficial soil of Guiyang, Guizhou. 


\subsection{Sampling}

The snake-form distribution sampling method was adopted because of the bigger sampling area, relief topography and un-uniform soil. The topsoil layer $(5 \sim 15 \mathrm{~cm})$ was sampled after cover rock and remained roots were removed(HJ/T 166-2004). Guiyang has 1286 villages 83 towns and the sample of $\mathrm{Hg}, \mathrm{Cd}, \mathrm{Pb}, \mathrm{Cr}$ and As localities were distributed in 487villages and 75 towns of Guiyang. So the samples account for $37.87 \%$ and $90.36 \%$, respectively. The sample of $\mathrm{Cu}, \mathrm{Ni}$ and $\mathrm{Zn}$ localities were distributed in 332 villages and 50 towns, and the samples account for $25.82 \%$ and $60.24 \%$. $\mathrm{Hg}, \mathrm{Cd}, \mathrm{Pb}, \mathrm{Cr}$ and As localities are shown in Fig. 3. $\mathrm{Cu}, \mathrm{Ni}$ and $\mathrm{Zn}$ localities are shown in Fig. 4.

The soil samples were collected 67 at January19 to March 4, and 420 at July 11 to October 11.

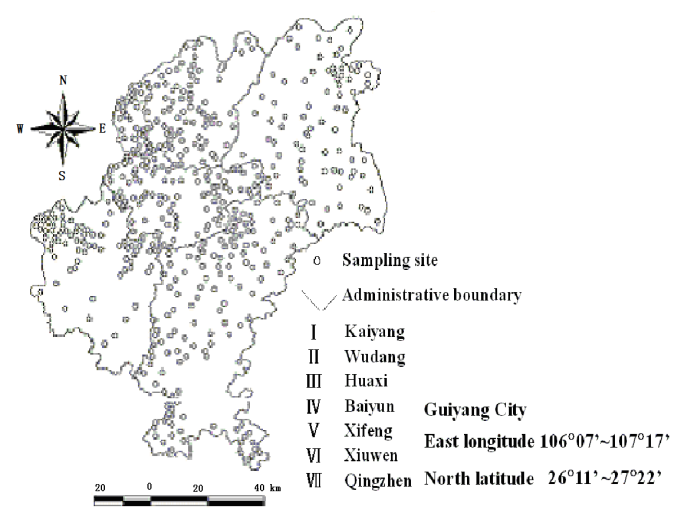

Fig. 3. The distribution on of $\mathrm{Cd}, \mathrm{Hg}, \mathrm{Cr}, \mathrm{Pb}$, As sites in Guiyang, Guizhou.

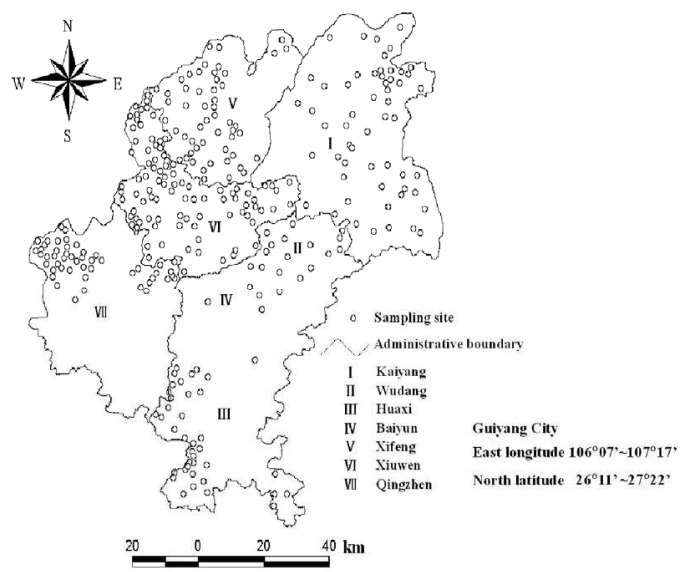

Fig. 4. The distribution on of $\mathrm{Cu}, \mathrm{Zn}$, Ni sites in Guiyang, Guizhou.

\subsection{Analytical techniques}

The content of As was digested with a mixture acids: $\mathrm{H}_{2} \mathrm{SO}_{4}-\mathrm{HNO}_{3}-\mathrm{HClO}_{4}\left(\mathrm{H}_{2} \mathrm{SO}_{4} / \mathrm{HNO}_{3} /\right.$ $\left.\mathrm{HClO}_{4}, 1: 1: 3\right)$ and using diethyl disulfide generation amino acid silver spectrophotometric 
method to determine the contents of As in the samples(GB/T17134-1997). The limits of determination were $0.5 \mathrm{mg} / \mathrm{kg}$ (As) according to $0.5 \mathrm{~g}$ sample which was dispelled in $50 \mathrm{ml}$. The content of $\mathrm{Pb}$ and $\mathrm{Cd}$ were digested with mixture acids: $\mathrm{HCl}-\mathrm{HNO}_{3}-\mathrm{HF}-\mathrm{HClO}_{4}$, and using graphite furnace atomic absorption spectrometry to determine the contents of $\mathrm{Pb}$ and $\mathrm{Cd}$, the limits of determination were $0.1 \mathrm{mg} / \mathrm{kg}(\mathrm{Pb}), 0.01 \mathrm{mg} / \mathrm{kg}(\mathrm{Cd})$ according to $0.5 \mathrm{~g}$ samples which were dispelled in $50 \mathrm{ml}(\mathrm{GB} / \mathrm{T} 17141-1997)$. The total content of Cr were determined by diethyl carbon phenol by two spectrophotometric method after the samples were digested with a mixture acids: $\mathrm{HCl}-\mathrm{HNO}_{3}-\mathrm{HF}$, and the limits of determination was $1.0 \mathrm{mg} / \mathrm{kg}(\mathrm{Cr})$ according to $0.5 \mathrm{~g}$ samples which was dispelled in 50ml (GB/T17137-1997). Using flame-atomic absorption spectrophotometry to determine the contents of $\mathrm{Cu}, \mathrm{Zn}$ and $\mathrm{Ni}$ in the samples(Cu and Zn: GB/T17138-1997; Ni: GB/T17139-1997). The limits of determination were $1.0 \mathrm{mg} / \mathrm{kg}(\mathrm{Cu}), 5.0 \mathrm{mg} / \mathrm{kg}(\mathrm{Ni}), 0.5 \mathrm{mg} / \mathrm{kg}(\mathrm{Zn})$ according to $0.5 \mathrm{~g}$ sample which was dispelled in $50 \mathrm{ml}$. The samples of $\mathrm{Cu}, \mathrm{Ni}$ and $\mathrm{Zn}$ were digested with $\mathrm{HCl}-\mathrm{HNO}_{3}-\mathrm{HF}-\mathrm{HClO}_{4}$. The total content of $\mathrm{Hg}$ was digested with a mixture of ultrapure acids: $\mathrm{H}_{2} \mathrm{SO}_{4}-\mathrm{HNO}_{3}-\mathrm{KMnO}_{4}\left(\mathrm{H}_{2} \mathrm{SO}_{4} / \mathrm{HNO}_{3}, 1: 1\right)$ and analyzed by cold atomic absorbent spectrophotometry, the limits of determination was $0.005 \mathrm{mg} / \mathrm{kg}(\mathrm{Hg})$ according to $2 \mathrm{~g}$ samples which was dispelled in 50ml(GB/T17136-1997). The concentrations of $\mathrm{Hg}, \mathrm{Pb}, \mathrm{Cd}$, $\mathrm{Cr}, \mathrm{Cu}, \mathrm{As}, \mathrm{Ni}$ and $\mathrm{Zn}$ in the solution were measured under the optimum condition. For quality assurance and quality control, reagent blanks, 20\% duplicated samples and sol standard reference materials GSS-1, GSS-3, GSS-4 obtained from Center of National Standard Reference Material of China were prepared and analyzed with the same procedure and reagents.

The table 1 showed that the accuracy and precision of testing of the above.

The available data sets were analyzed using the SPSS 16.0, ArcGIS, and ArcView.

\begin{tabular}{cccccccc}
\hline Elements & SU & SS & GV $(\mathrm{mg} / \mathrm{kg})$ & ORM $(\mathrm{mg} / \mathrm{kg})$ & IRSD $(\%)$ & RSDBR $(\%)$ & RE $(\%)$ \\
\hline \multirow{3}{*}{ As } & 14 & GSS-1 & $10.7 \pm 0.8$ & 10.7 & 2.0 & 5.6 & 0.0 \\
& 15 & GSS-3 & $15.9 \pm 1.3$ & 17.1 & 1.3 & 4.3 & 7.5 \\
& 12 & GSS-4 & $11.4 \pm 0.7$ & 11.4 & 3.8 & 4.8 & 0.0 \\
$\mathrm{Cd}$ & 25 & GSS-1 & $0.083 \pm 0.011$ & 0.080 & 3.6 & 6.2 & -3.6 \\
& 28 & GSS-3 & $0.044 \pm 0.014$ & 0.045 & 4.1 & 8.4 & 2.3 \\
$\mathrm{Cr}$ & 16 & GSS-1 & $57.2 \pm 4.2$ & 56.1 & 2.0 & 9.8 & -1.9 \\
& 18 & GSS-3 & $98.0 \pm 7.1$ & 93.2 & 2.3 & 8.3 & -4.9 \\
$\mathrm{Cu}$ & 35 & GSS-1 & $20.9 \pm 0.8$ & 20.7 & 2.3 & 6.8 & -0.96 \\
& 34 & GSS-3 & $29.4 \pm 1.6$ & 29.2 & 2.0 & 4.8 & -0.68 \\
& 30 & GSS-4 & $26.3 \pm 1.7$ & 25.6 & 2.3 & 3.9 & -2.7 \\
$\mathrm{Hg}$ & 25 & GSS-1 & $0.016 \pm 0.003$ & 0.016 & 6.2 & 32.5 & 0.0 \\
& 26 & GSS-3 & $0.112 \pm 0.012$ & 0.100 & 3.4 & 20.0 & -10.7 \\
& 24 & GSS-4 & $0.021 \pm 0.004$ & 0.019 & 8.4 & 20.5 & -9.5 \\
$\mathrm{Ni}$ & 29 & GSS-1 & $29.6 \pm 1.8$ & 29.1 & 2.5 & 8.4 & -1.7 \\
& 32 & GSS-3 & $33.7 \pm 2.1$ & 34.0 & 2.6 & 6.0 & 0.89 \\
$\mathrm{Fb}$ & 33 & GSS-4 & $32.8 \pm 1.7$ & 34.1 & 2.9 & 9.1 & 4.0 \\
& 19 & GSS-1 & $23.6 \pm 1.2$ & 23.7 & 4.2 & 7.3 & 0.42 \\
$\mathrm{Zn}$ & 21 & GSS-3 & $33.3 \pm 1.3$ & 33.7 & 3.9 & 8.6 & 1.2 \\
& 32 & GSS-1 & $55.2 \pm 3.4$ & 56.2 & 2.8 & 7.3 & 1.8 \\
& 31 & GSS-3 & $89.3 \pm 4.0$ & 88.4 & 1.6 & 5.0 & 1.0 \\
& 31 & GSS-4 & $69.1 \pm 3.5$ & 68.1 & 3.2 & 4.1 & -1.4 \\
\hline
\end{tabular}

SU: sample numbers; SS: standard samples; GV: guaranteed value; ORM: overall mean IRSD: indoor relative standard deviation; RSDBR: relative standard between room; RE: relative error

Table 1. The accuracy and precision of contents of heavy metals in soil. 


\section{Experimental results}

Table2 indicated that the statistical analysis results of soil heavy metals concentrations in Guiyang city. The mean value, standard deviation and maximum of As separately are 18.09 $\mathrm{mg} / \mathrm{kg}, 11.57 \mathrm{mg} / \mathrm{kg}$ and $79.30 \mathrm{mg} / \mathrm{kg}$ in the surficial soil in Guiyang. The content of As in 95.9 per cent sample are smaller than $40 \mathrm{mg} / \mathrm{kg}$., of $\mathrm{Cd}$ separately are $0.302 \mathrm{mg} / \mathrm{kg}$, $0.363 \mathrm{mg} / \mathrm{kg}, 2.620 \mathrm{mg} / \mathrm{kg}$ and 95.7 percent smaller than $1.000 \mathrm{mg} / \mathrm{kg}$., of $\mathrm{Cr} 75.3 \mathrm{mg} / \mathrm{kg}$, 37.3 $\mathrm{mg} / \mathrm{kg}, 271.0 \mathrm{mg} / \mathrm{kg}$ and 95.9 percent smaller than $150.0 \mathrm{mg} / \mathrm{kg}$, of $\mathrm{Cu}$ separately are $43.1 \mathrm{mg} / \mathrm{kg}, 30.3 \mathrm{mg} / \mathrm{kg}, 213.0 \mathrm{mg} / \mathrm{kg}$ and 94.6 percent smaller than $100.0 \mathrm{mg} / \mathrm{kg}$, of $\mathrm{Pb}$ are $43.2 \mathrm{mg} / \mathrm{kg}, 31.3 \mathrm{mg} / \mathrm{kg}, 318.9 \mathrm{mg} / \mathrm{kg}$ and 95.5 per cent smaller than $100.0 \mathrm{mg} / \mathrm{kg}$, of $\mathrm{Hg}$ are $0.222 \mathrm{mg} / \mathrm{kg}, 0.531 \mathrm{mg} / \mathrm{kg}, 7.030 \mathrm{mg} / \mathrm{kg}$ and 98.2 smaller than $1.000 \mathrm{mg} / \mathrm{kg}$, of $\mathrm{Ni}$ are $38.3 \mathrm{mg} / \mathrm{kg}, 14.9 \mathrm{mg} / \mathrm{kg}, 102.5 \mathrm{mg} / \mathrm{kg}$ and 95.8 percent smaller than $70.0 \mathrm{mg} / \mathrm{kg}$, of $\mathrm{Zn}$ are $84.7 \mathrm{mg} / \mathrm{kg}, 49.8 \mathrm{mg} / \mathrm{kg}, 385.0 \mathrm{mg} / \mathrm{kg}$ and 94.3 percent smaller than $150.0 \mathrm{mg} / \mathrm{kg}$.

\begin{tabular}{ccccccc}
\hline Elements & SN & $\operatorname{Min}\left(10^{-6}\right)$ & $\operatorname{Max}\left(10^{-6}\right)$ & $\operatorname{Mean}\left(10^{-6}\right)$ & SD & CV \\
\hline $\mathrm{As}$ & 486 & 2.70 & 79.00 & 18.09 & 11.57 & 0.64 \\
$\mathrm{Cd}$ & 487 & 0.001 & 2.620 & 0.302 & 0.363 & 1.20 \\
$\mathrm{Cr}$ & 487 & 6.9 & 271.0 & 75.3 & 37.3 & 0.50 \\
$\mathrm{Cu}$ & 333 & 2.1 & 213.0 & 43.1 & 30.3 & 0.70 \\
$\mathrm{~Pb}$ & 487 & 0.9 & 318.9 & 43.2 & 31.3 & 0.7 \\
$\mathrm{Hg}$ & 487 & 0.010 & 7.030 & 0.222 & 0.531 & 2.39 \\
$\mathrm{Ni}$ & 333 & 9.2 & 102.5 & 38.3 & 14.9 & 0.39 \\
$\mathrm{Zn}$ & 333 & 0.1 & 385.0 & 84.7 & 49.8 & 0.59 \\
\hline
\end{tabular}

$\mathrm{SN}$ : sample numbers; SD: standard deviation; $\mathrm{CV}$ : coefficient of variation

Table 2. The statistical analysis results of heavy metals concentration in soil, Guiyang city.

\section{Analysis and discussions}

\subsection{Results analysis}

\subsubsection{Establishment of the baselines of heavy metals in surficial soil}

\subsubsection{Establishment of the baselines of As in surficial soil}

\subsection{Relatively accumulative total amount analysis}

Assuming the concentrations of chemical elements in natural surficial soil are of logarithmic normal distribution, the inflexion in the figure of relatively accumulative density to the concentration of chemical element represents the boundary line between the background value and the abnormal value. The range of baseline values of chemical elements is the average value plus double standard deviation of less than the boundary value (Lepeltier, 1969).

The double logarithmic figure of relatively accumulative density (RAD) to the concentration of the chemical element As in topsoil of Guiyang was shown in Fig.5. The inflexion (black points in the figure) is $17.2 \mathrm{mg} / \mathrm{kg}$. So the range of baseline values of As in topsoil of Guiyang is $7.75 \sim 15.15 \mathrm{mg} / \mathrm{kg}$, i.e., the average value of $11.45 \mathrm{mg} / \mathrm{kg}$ plus a double standard deviation of $3.70 \mathrm{mg} / \mathrm{kg}$ less than $17.2 \mathrm{mg} / \mathrm{kg}$. 


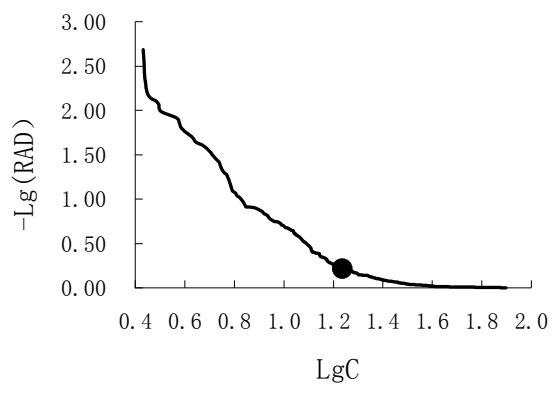

Fig. 5. The logarithm of the concentrations on As and the logarithmic curve of relatively accumulative density in surficial soil.

\subsection{Relatively accumulative frequency}

The normal decimal coordinates are adopted. There are two inflexions in the figures of relatively accumulative frequency to the concentration of chemical element. The lower one may represent the upper limit of the baseline of chemical elements and the upper one may represent the lower limit of abnormity, i.e., the influence of human activity on the two inflexions. The average or median that is less than the lower inflexion can be regarded as the baseline of chemical elements. The metrical values between the two inflexions may have something with the influence of human activities, or have nothing to do. If the distribution curve looks like a straight line, the measured values may represent the baseline range (Bauer \& Bor,1993,1995); Bauer et al.1992; Matschullatetc, 2000)

The figure of relatively accumulative frequency to the concentration of As in topsoil of Guiyang is shown in Fig.6. There are two inflexions: one is $13.0 \mathrm{mg} / \mathrm{kg}$ and the other is $29.0 \mathrm{mg} / \mathrm{kg}$. So the first inflexion $(13.0 \mathrm{mg} / \mathrm{kg})$ represents the upper limit of baseline values of As in topsoil of Guiyang. The average of $9.20 \mathrm{mg} / \mathrm{kg}$ or the median of $9.04 \mathrm{mg} / \mathrm{kg}$ less than the first-inflexion can be regarded as the baseline of As in topsoil of Guiyang. The second inflexion $(29.0 \mathrm{mg} / \mathrm{kg})$ may represent abnormity, i.e., the influence of human activity.

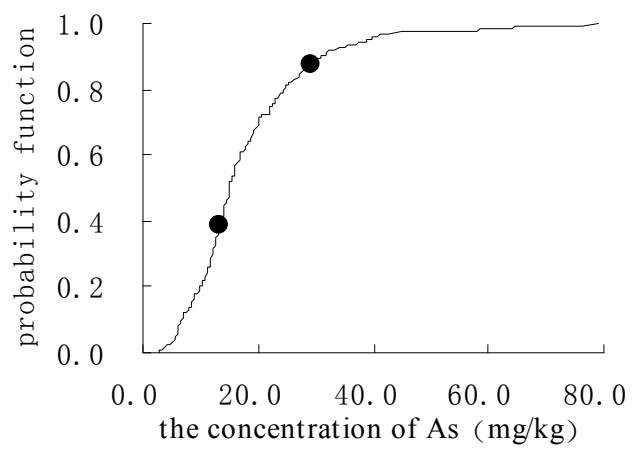

Fig. 6. The probability functions of As in surficial soil. 
Comprehensively considering the results of calculation using the two kinds of methods, we respectively take $9.04 \mathrm{mg} / \mathrm{kg}$ as the baseline values of As in topsoil of Guiyang.

\subsubsection{Establishment of the baselines of $\mathrm{Cd}$ in surficial soil}

\subsection{Relatively accumulative total amount analysis}

The double logarithmic figure of RAD to the concentration of the chemical element $\mathrm{Cd}$ in topsoil of Guiyang was shown in Fig.7. The inflexion (black points in the figure) is 0.189 $\mathrm{mg} / \mathrm{kg}$. So the range of baseline values of Cd in topsoil of Guiyang is $0.029 \sim 0.123 \mathrm{mg} / \mathrm{kg}$, i.e. the average value of $0.076 \mathrm{mg} / \mathrm{kg}$ pluses double standard deviation of $0.047 \mathrm{mg} / \mathrm{kg}$ less than $0.189 \mathrm{mg} / \mathrm{kg}$.

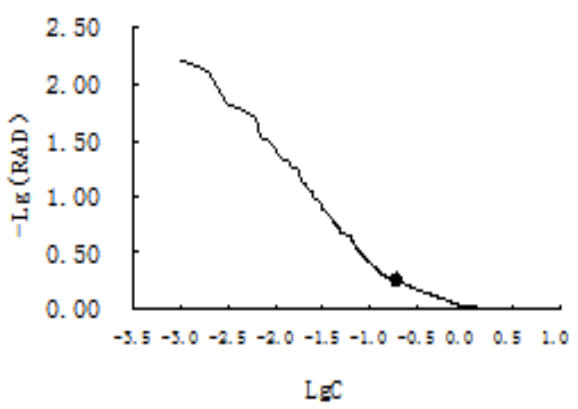

Fig. 7. The logarithm of the concentration on $\mathrm{Cd}$ and the logarithmic curve of relatively accumulative density in surficial soil.

\subsection{Relatively accumulative frequency}

The figure of relatively accumulative frequency to the concentration of $\mathrm{Cd}$ is shown in Fig.8. One inflexion is $0.149 \mathrm{mg} / \mathrm{kg}$ and the other is $1.010 \mathrm{mg} / \mathrm{kg}$. So the first inflexion $(0.149$ $\mathrm{mg} / \mathrm{kg}$ ) represents the upper limit of baseline values of $\mathrm{Cd}$ in topsoil of Guiyang. The average of $0.068 \mathrm{mg} / \mathrm{kg}$ or the median of $0.068 \mathrm{mg} / \mathrm{kg}$ less-than the first inflexion can be regarded as the baseline of $\mathrm{Cd}$ in topsoil of Guiyang. The second inflexion $(1.010 \mathrm{mg} / \mathrm{kg})$ may regard as represent abnormity, i.e., the influence of human activities.

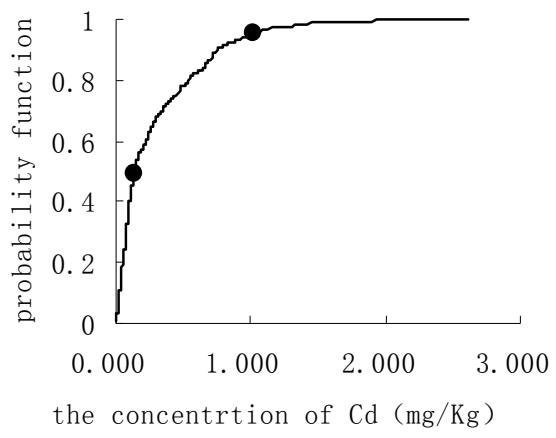

Fig. 8. The probability functions of $\mathrm{Cd}$ in surfucial soil of Guiyang. 
Comprehensively considering the results of calculation using the two kinds of methods, we respectively take $0.068 \mathrm{mg} / \mathrm{kg}$ as the baseline values of Cd in topsoil of Guiyang.

\subsubsection{Establishment of the baselines of $\mathrm{Cu}$ in surficial soil}

\subsection{Relatively accumulative total amount analysis}

The double logarithmic figure of RAD to the concentration of the chemical element $\mathrm{Cu}$ in topsoil of Guiyang is shown in Fig.9. The inflexion (black points in the figure) is $32.6 \mathrm{mg} / \mathrm{kg}$. So the range of baseline values of $\mathrm{Cu}$ in topsoil of Guiyang is $14.2 \sim 28.4 \mathrm{mg} / \mathrm{kg}$, i.e., the average value of $21.3 \mathrm{mg} / \mathrm{kg}$ pluses a double standard deviation of $7.1 \mathrm{mg} / \mathrm{kg}$ less than 32.6 $\mathrm{mg} / \mathrm{kg}$.

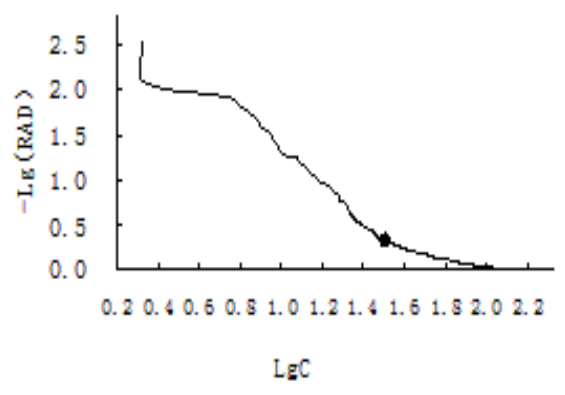

Fig. 9. The logarithm of the concentrations on $\mathrm{Cu}$ and the logarithmic curve of relatively accumulative density in surficial soil.

\subsection{Relatively accumulative frequency}

The figure of relatively accumulative frequency to the concentration of $\mathrm{Cu}$ in topsoil of Guiyang is shown in Fig.10. There are two inflexions: one is $28.1 \mathrm{mg} / \mathrm{kg}$ and the other is 68.4 $\mathrm{mg} / \mathrm{kg}$. So the first inflexion $(28.1 \mathrm{mg} / \mathrm{kg})$ represents the upper limit of baseline values of $\mathrm{Cu}$ in topsoil of Guiyang. The average of $18.8 \mathrm{mg} / \mathrm{kg}$ or the median of $21.9 \mathrm{mg} / \mathrm{kg}$ less than the first-inflexion can be regarded as the baseline of $\mathrm{Cu}$ in topsoil of Guiyang. The second inflexion $(68.4 \mathrm{mg} / \mathrm{kg}$ ) may represent abnormity, i.e., the influence of human activity.

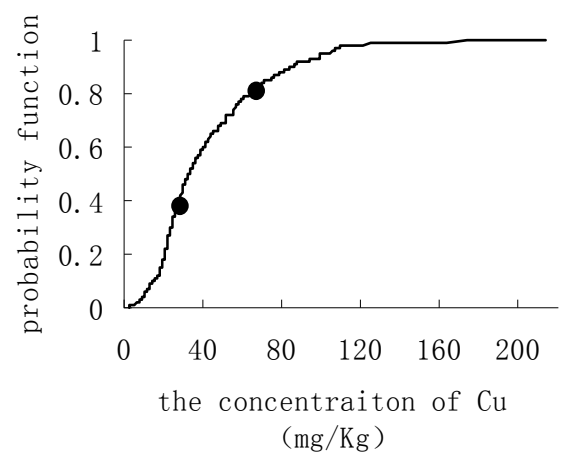

Fig. 10. The probability functions of $\mathrm{Cu}$ in surficial soil. 
Comprehensively considering the results of calculation using the two kinds of methods, we respectively take $18.8 \mathrm{mg} / \mathrm{kg}$ as the baseline values of $\mathrm{Cu}$ in topsoil of Guiyang.

\subsubsection{Establishment of the baselines of $\mathrm{Zn}$ in surficial soil}

\subsection{Relatively accumulative total amount analysis}

The double logarithmic figure of RAD to the concentration of the chemical element $\mathrm{Zn}$ in topsoil of Guiyang is shown in Fig.11. The inflexion is $114.0 \mathrm{mg} / \mathrm{kg}$. So the range of baseline values of $\mathrm{Zn}$ in topsoil of Guiyang is $46.5 \sim 91.3 \mathrm{mg} / \mathrm{kg}$, i.e., the average value of $68.9 \mathrm{mg} / \mathrm{kg}$ pluses double standard deviation of $22.4 \mathrm{mg} / \mathrm{kg}$ less than $114.0 \mathrm{mg} / \mathrm{kg}$.

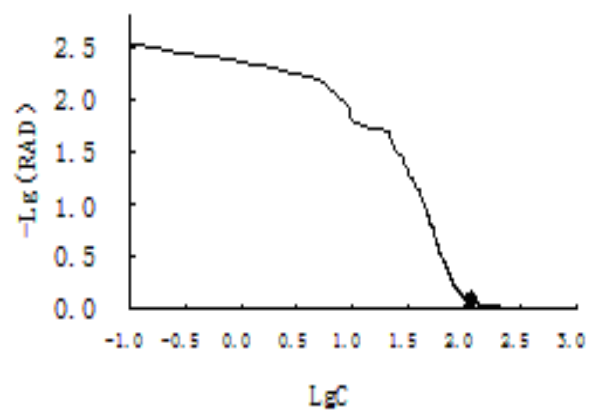

Fig. 11. The logarithm of the concentrations on $\mathrm{Zn}$ and the logarithmic curve of relatively accumulative density in surficial soil.

\subsection{Relatively accumulative frequency}

The figure of relatively accumulative frequency to the concentration of $\mathrm{Zn}$ in topsoil of Guiyang is shown in Fig.12. There are two inflexions. One inflexion is $56.5 \mathrm{mg} / \mathrm{kg}$ and the other is $112.0 \mathrm{mg} / \mathrm{kg}$. So the first inflexion $(56.5 \mathrm{mg} / \mathrm{kg})$ represents the upper limit of baseline values of $\mathrm{Zn}$ in topsoil of Guiyang. The average of $41.6 \mathrm{mg} / \mathrm{kg}$ or the median of $46.3 \mathrm{mg} / \mathrm{kg}$ less-than the first inflexion can be regarded as the baseline of $\mathrm{Zn}$ in topsoil of Guiyang. The second inflexion $(112.0 \mathrm{mg} / \mathrm{kg})$ may regard as represent abnormity, i.e., the influence of human activities.

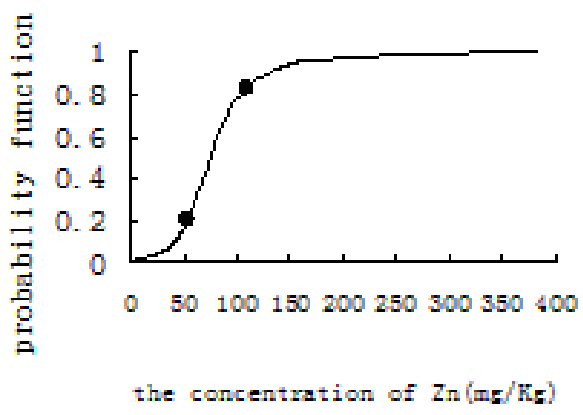

Fig. 12. The probability functions of $\mathrm{Zn}$ in surficial soil. 
Comprehensively considering the results of calculation using the two kinds of methods, we respectively take $46.3 \mathrm{mg} / \mathrm{kg}$ as the baseline values of $\mathrm{Zn}$ in topsoil of Guiyang.

\subsubsection{Establishment of the baselines of $\mathrm{Pb}$ in surficial soil}

\subsection{Relatively accumulative total amount analysis}

The double logarithmic figure of RAD to the concentration of the chemical element $\mathrm{Pb}$ in topsoil of Guiyang is shown in Fig.13. The inflexion (black points in the figure) is 26.8 $\mathrm{mg} / \mathrm{kg}$. So the range of baseline values of $\mathrm{Pb}$ in topsoil of Guiyang is $14.0 \sim 25.4 \mathrm{mg} / \mathrm{kg}$, i.e., the average value of $19.7 \mathrm{mg} / \mathrm{kg}$ pluses a double standard deviation of $5.7 \mathrm{mg} / \mathrm{kg}$ less than $26.8 \mathrm{mg} / \mathrm{kg}$.

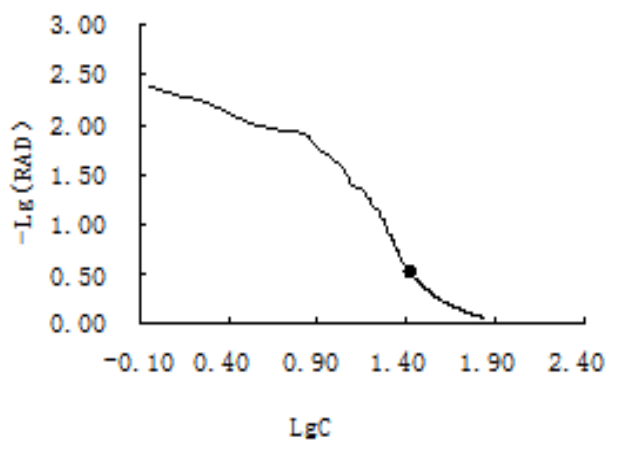

Fig. 13. The logarithm of the concentrations on $\mathrm{Pb}$ and the logarithmic curve of relatively accumulative density in surficial soil.

\subsection{Relatively accumulative frequency}

The figure of relatively accumulative frequency to the concentration of $\mathrm{Pb}$ in topsoil of Guiyang is shown in Fig.14. There are two inflexions: one is $20.4 \mathrm{mg} / \mathrm{kg}$ and the other is $70.1 \mathrm{mg} / \mathrm{kg}$. So the first inflexion $(20.4 \mathrm{mg} / \mathrm{kg}$ ) represents the upper limit of baseline values of $\mathrm{Pb}$ in topsoil of Guiyang. The average of $16.0 \mathrm{mg} / \mathrm{kg}$ or the median of $14.8 \mathrm{mg} / \mathrm{kg}$ less than the first-inflexion can be regarded as the baseline of $\mathrm{Pb}$ in topsoil of Guiyang. The second inflexion $(70.1 \mathrm{mg} / \mathrm{kg}$ ) may represent abnormity, i.e., the influence of human activity.

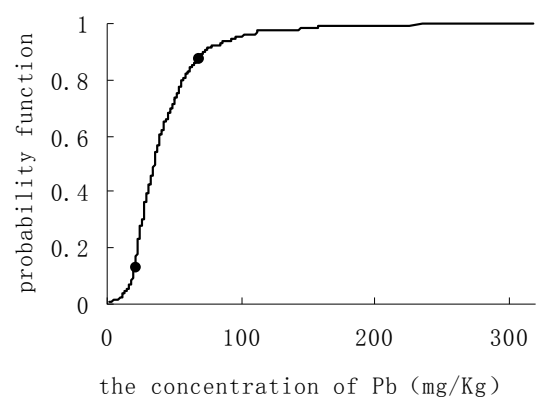

Fig. 14. The probability functions of $\mathrm{Pb}$ in surficial soil of Guiyang. 
Comprehensively considering the results of calculation using the two kinds of methods, we respectively take $14.8 \mathrm{mg} / \mathrm{kg}$ as the baseline values of $\mathrm{Pb}$ in topsoil of Guiyang.

\subsubsection{Establishment of the baselines of $\mathrm{Hg}$ in surficial soil}

\subsection{Relatively accumulative total amount analysis}

The double logarithmic figure of RAD to the concentration of the chemical element $\mathrm{Hg}$ in topsoil of Guiyang is shown in Fig.15. The inflexion (black points in the figure) is 0.082 $\mathrm{mg} / \mathrm{kg}$. So the range of baseline values of $\mathrm{Hg}$ in topsoil of Guiyang is $0.031 \sim 0.075 \mathrm{mg} / \mathrm{kg}$, i.e., the average value of $0.053 \mathrm{mg} / \mathrm{kg}$ pluses double standard deviation of $0.022 \mathrm{mg} / \mathrm{kg}$ less than $0.082 \mathrm{mg} / \mathrm{kg}$.

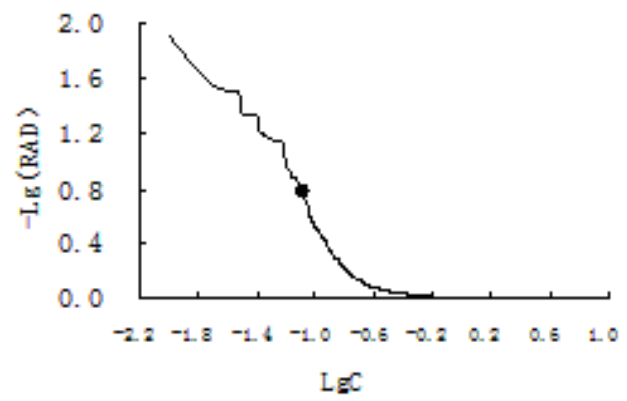

Fig. 15. The logarithm of the concentrations on $\mathrm{Hg}$ and the logarithmic curve of relatively accumulative density in surficial soil.

\subsection{Relatively accumulative frequency}

The figure of relatively accumulative frequency to the concentration of $\mathrm{Hg}$ in topsoil of Guiyang is shown in Fig.16. There are two inflexions. One inflexion is $0.072 \mathrm{mg} / \mathrm{kg}$ and the other is $0.530 \mathrm{mg} / \mathrm{kg}$. So the first inflexion $(0.072 \mathrm{mg} / \mathrm{kg})$ represents the upper limit of baseline values of $\mathrm{Hg}$ in topsoil of Guiyang. The average of $0.050 \mathrm{mg} / \mathrm{kg}$ or the median of $0.045 \mathrm{mg} / \mathrm{kg}$ less-than the first inflexion can be regarded as the baseline of $\mathrm{Hg}$ in topsoil of Guiyang. The second inflexion $(0.530 \mathrm{mg} / \mathrm{kg})$ may regard as represent abnormity, i.e., the influence of human activities.

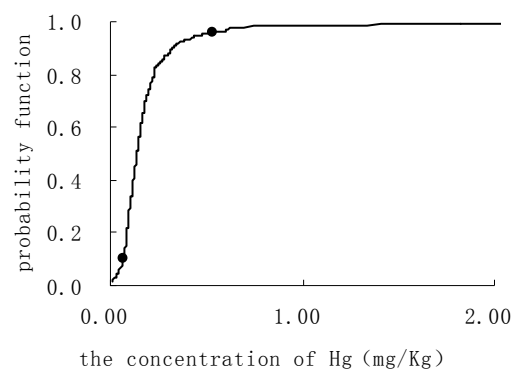

Fig. 16. The probability functions of $\mathrm{Hg}$ in surficial soil. 
Comprehensively considering the results of calculation using the two kinds of methods, we respectively take $0.045 \mathrm{mg} / \mathrm{kg}$ as the baseline values $\mathrm{Hg}$ in topsoil of Guiyang.

\subsubsection{Establishment of the baselines of $\mathrm{Cr}$ in surficial soil}

\subsection{Relatively accumulative total amount analysis}

The double logarithmic figure of RAD to the concentration of the chemical element $\mathrm{Cr}$ in topsoil of Guiyang is shown in Fig.17. The inflexion (black points in the figure) is 67.8 $\mathrm{mg} / \mathrm{kg}$. So the range of baseline values of $\mathrm{Cr}$ in topsoil of Guiyang is $31.0 \sim 59.8 \mathrm{mg} / \mathrm{kg}$, i.e., the average value of $45.4 \mathrm{mg} / \mathrm{kg}$ pluses a double standard deviation of $14.4 \mathrm{mg} / \mathrm{kg}$ less than $67.8 \mathrm{mg} / \mathrm{kg}$.

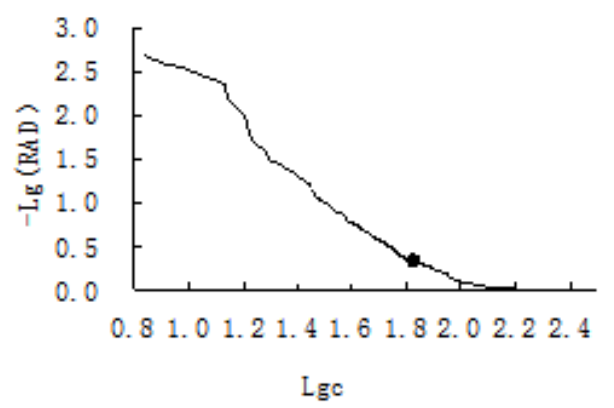

Fig. 17. The logarithm of the concentrations on $\mathrm{Cr}$ and the logarithmic curve of relatively accumulative density in surficial soil.

\subsection{Relatively accumulative frequency}

The figure of relatively accumulative frequency to the concentration of $\mathrm{Cr}$ in topsoil of Guiyang is shown in Fig.18. There are two inflexions: one is $63.8 \mathrm{mg} / \mathrm{kg}$ and the other is 100.2 $\mathrm{mg} / \mathrm{kg}$. So the first inflexion $(63.8 \mathrm{mg} / \mathrm{kg})$ represents the upper limit of baseline values of $\mathrm{Cr}$ in topsoil of Guiyang. The average of $45.7 \mathrm{mg} / \mathrm{kg}$ or the median of $44.0 \mathrm{mg} / \mathrm{kg}$ less than the first-inflexion can be regarded as the baseline of $\mathrm{Cr}$ in topsoil of Guiyang. The second inflexion $(100.2 \mathrm{mg} / \mathrm{kg})$ may represent abnormity, i.e., the influence of human activity.

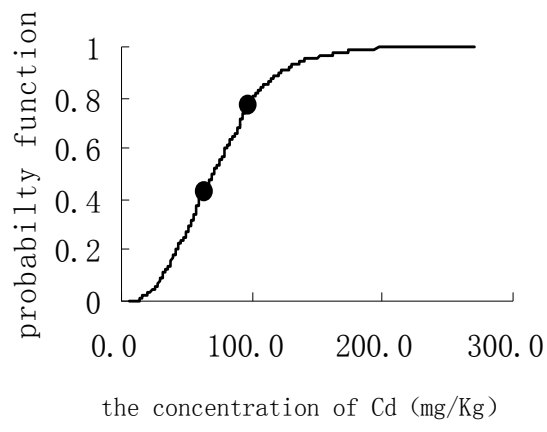

Fig. 18. The probability functions of Cr in surficial soil. 
Comprehensively considering the results of calculation using the two kinds of methods, we respectively take $44.0 \mathrm{mg} / \mathrm{kg}$ as the baseline values of $\mathrm{Cr}$ in topsoil of Guiyang.

\subsubsection{Establishment of the baselines of $\mathrm{Ni}$ in surficial soil}

\subsection{Relatively accumulative total amount analysis}

The double logarithmic figure of RAD to the concentration of the chemical element $\mathrm{Ni}$ in topsoil of Guiyang is shown in Fig.19. The inflexion is $27.6 \mathrm{mg} / \mathrm{kg}$. So the range of baseline values of $\mathrm{Ni}$ in topsoil of Guiyang is $18.1 \sim 26.7 \mathrm{mg} / \mathrm{kg}$, i.e., the average value of $22.4 \mathrm{mg} / \mathrm{kg}$ pluses double standard deviation of $4.3 \mathrm{mg} / \mathrm{kg}$ less than $27.6 \mathrm{mg} / \mathrm{kg}$.

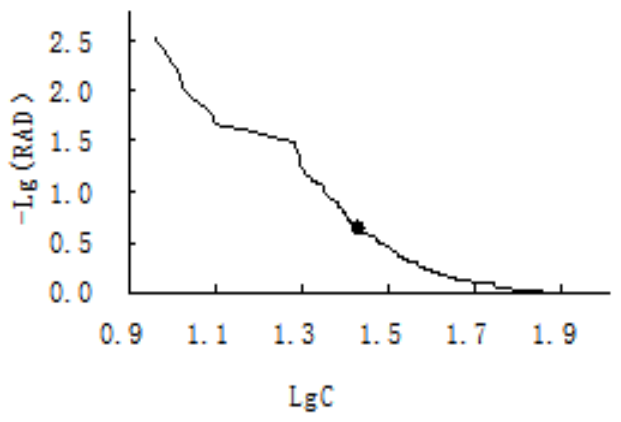

Fig. 19. The logarithm of the concentrations on $\mathrm{Ni}$ and the logarithmic curve of relatively accumulative density in surficial soil.

\subsection{Relatively accumulative frequency}

The figure of relatively accumulative frequency to the concentration of $\mathrm{Ni}$ in topsoil of Guiyang is shown in Fig.20. There are two inflexions. One inflexion is $27.8 \mathrm{mg} / \mathrm{kg}$ and the other is $57.0 \mathrm{mg} / \mathrm{kg}$. So the first inflexion $(27.8 \mathrm{mg} / \mathrm{kg})$ represents the upper limit of baseline values of $\mathrm{Ni}$ in topsoil of Guiyang. The average of $19.5 \mathrm{mg} / \mathrm{kg}$ or the median of $17.0 \mathrm{mg} / \mathrm{kg}$ less-than the first inflexion can be regarded as the baseline of $\mathrm{Ni}$ in topsoil of Guiyang. The second inflexion $(57.0 \mathrm{mg} / \mathrm{kg})$ may regarded as represent abnormity, i.e., the influence of human activities.

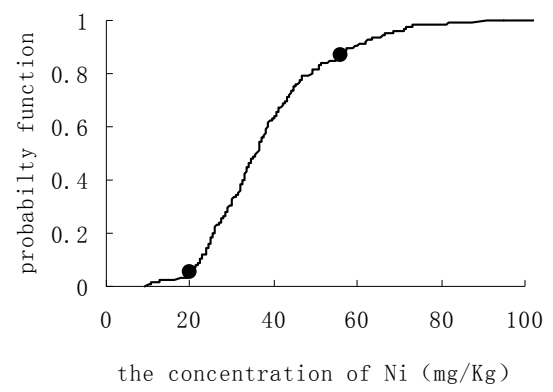

Fig. 20. The probability functions of $\mathrm{Ni}$ in surficial soil. 
Comprehensively considering the results of calculation using the two kinds of methods, we respectively take $17.0 \mathrm{mg} / \mathrm{kg}$ as the baseline values of $\mathrm{Ni}$ in topsoil of Guiyang.

\subsection{Discussions}

\subsubsection{Geo-accumulation analysis of heavy metals in surficial soil}

Geo-accumulation Index was commonly called Muller Index (Muller, 1969; Forstner \& Muller, 1981), was widely used in studying quantitative index for heavy metals pollution in sediments (Forstner et al., 1990; Chen Cuihua et al.,2008; Yi xiu et al.,2010; Hu Mianhao, 2010), and the expression as this.

$$
I_{\text {geo }}=\log _{2}\left[\frac{c_{n}}{1.5 \bullet B E_{n}}\right]
$$

$C_{\mathrm{n}}$ represents the concentration of element $\mathbf{n}$ in sample. $B E_{\mathrm{n}}$ means the baseline concentration, 1.5 was modified index for characterizing sedimentary characteristics, rocky and other effects.

Geo-accumulation Index can be divided into several levels, e.g. it was divided into seven levels by Forstner (referred to hereafter as F classification), and five levels by Anon (referred to hereafter as A classification). It indicated pollution degrees of heavy metals by different classes of $I_{\text {geo }}$.

\begin{tabular}{cccccc}
\hline \multicolumn{3}{c}{ F classification } & \multicolumn{3}{c}{ A classification } \\
\hline$I_{\text {geo }}$ & levels & Pollution degrees & $I_{\text {geo }}$ & levels & Pollution degrees \\
$<0$ & 1 & W.P. & $<0$ & 1 & W.P. or slight pollution \\
$0 \sim 1$ & 2 & W.P. to M.P. & $0 \sim 1$ & 2 & M.P. \\
$1 \sim 2$ & 3 & M.P. & $1 \sim 3$ & 3 & M.P. or S.P. \\
$2 \sim 3$ & 4 & M.P. to S.P. & $3 \sim 5$ & 4 & S.P. \\
$3 \sim 4$ & 5 & S.P. & $>5$ & 5 & S.S.P. \\
$4 \sim 5$ & 6 & S.P. to S.S.P. & & & \\
$>5$ & 7 & S.S.P. & & & \\
\hline
\end{tabular}

W.P.: without pollution; M.P.: mid-pollution; S.P.: strong pollution; S.S.P.: super strong pollution

Table 3. Degrees of pollution by heavy metals indicated by different classes of $I_{\text {geo }}$.

The means of Geo-accumulation indexes of heavy metals in surficial soil of Guiyang city were analyzed (Fig.21 to Fig.28). By the results, we get the surficial soil in 41 per cent of the Guiyang did not suffer the arsenic contaminative, 43 per cent is between without pollution to mid-pollution, 14 per cent mid-pollution, only 2 per cent is between mid-pollution to strong pollution. In 40 per cent did not suffer the cadmium contaminative, 19 per cent between without pollution to mid-pollution, 14 per cent mid-pollution, 19 per cent between mid-pollution to strong pollution, 7 per cent strong pollution, 1 per cent between strong pollution to supper strong pollution. In 46 per cent did not suffer the chromium contaminative, 47 per cent between without pollution to mid-pollution, 6.8 per cent midpollution, only 0.2 per cent between mid-pollution to strong pollution. In 38 per cent did not suffer the copper contaminative, 38 per cent between without pollution to mid-pollution, 22 per cent mid-pollution, only 2 per cent between mid-pollution to strong pollution. In 18 per 
cent did not suffer the lead contaminative, 47 per cent between without pollution to midpollution, 28 per cent mid-pollution, only 3 per cent between mid-pollution to strong pollution. In 12 per cent did not suffer the mercury contaminative, 37 per cent between without pollution to mid-pollution, 36 per cent mid-pollution, 11 per cent between midpollution to strong pollution, 2 per cent strong pollution, 1 per cent supper between strong pollution to supper strong pollution, 1 per cent supper strong pollution. In 19.2 per cent did not suffer the nickel contaminative, 63.7 per cent between without pollution to midpollution, 16.8 per cent mid-pollution, only 0.3 per cent between mid-pollution to strong pollution. In 41 per cent did not suffer the zinc contamination, 50per cent between without pollution to mid-pollution, 7 per cent mid-pollution, only 2 per cent between mid-pollution to strong pollution.

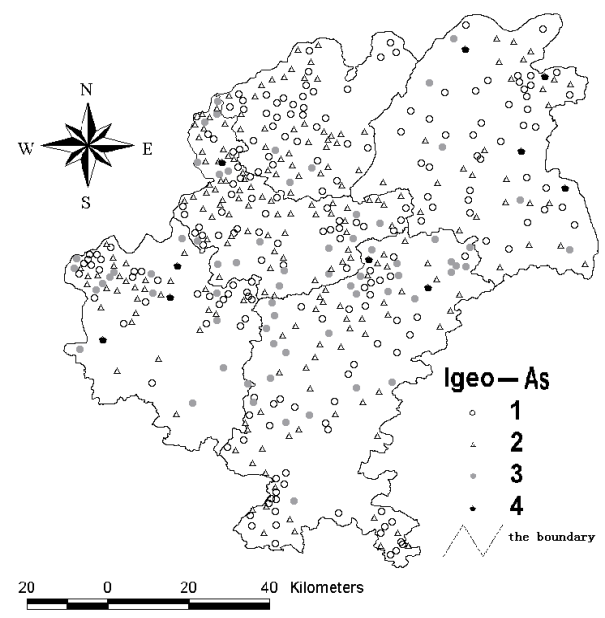

Fig. 21. Distribution of $I_{\text {geo }}$ for As in surficial soil.

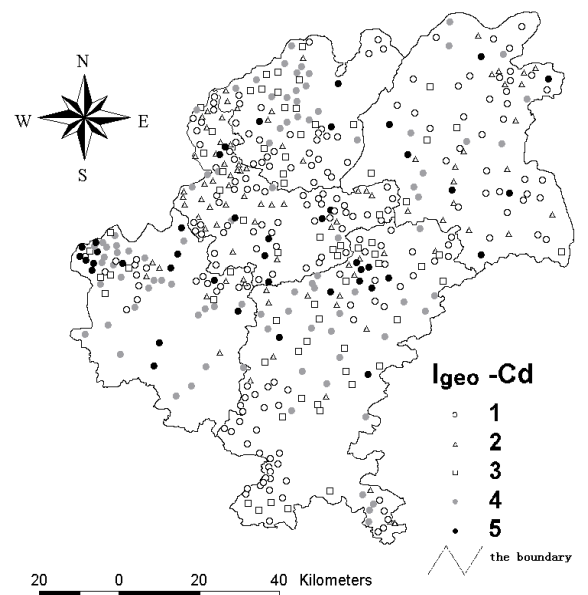

Fig. 22. Distribution of $I_{\text {geo }}$ for Cd in surficial soil. 


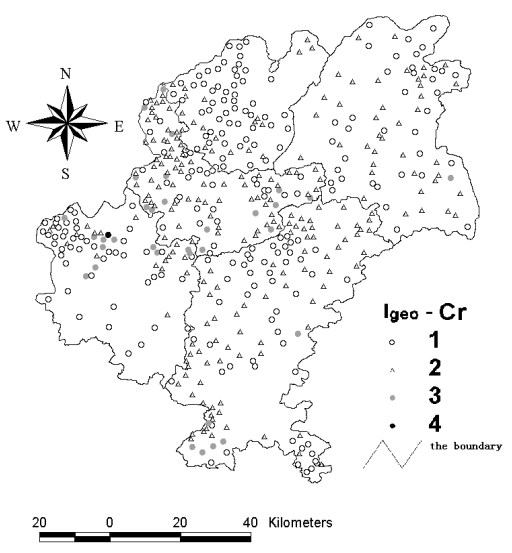

Fig. 23. Distribution of $I_{\text {geo }}$ for $\mathrm{Cr}$ in surficial soil.

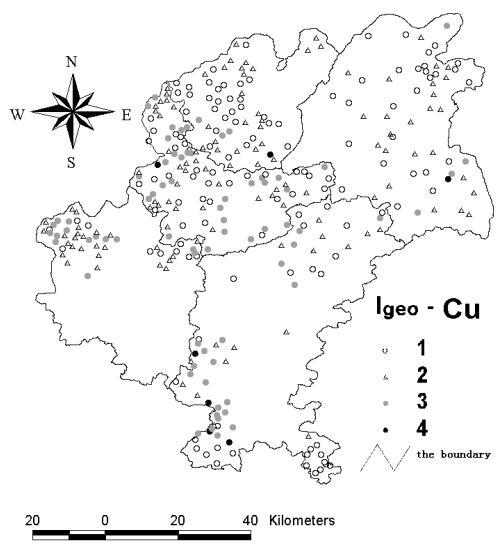

Fig. 24. Distribution of $I_{\text {geo }}$ for $\mathrm{Cu}$ in surficial soil.

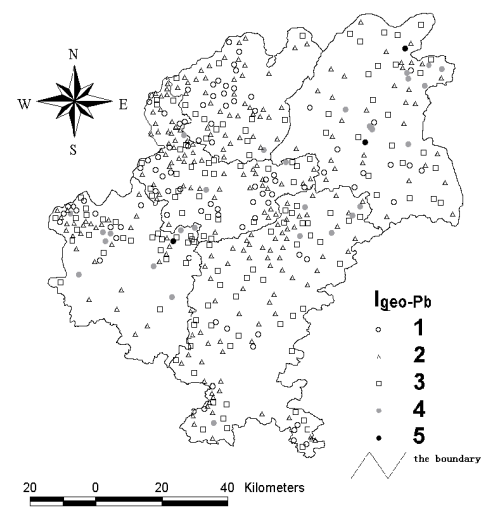

Fig. 25. Distribution of $I_{\text {geo }}$ for $\mathrm{Pb}$ in surficial soil. 


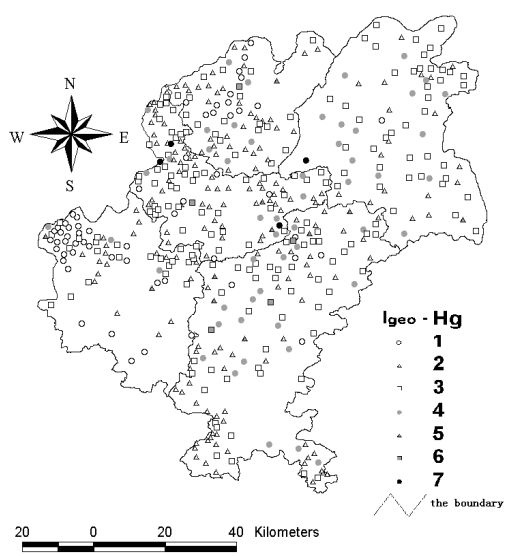

Fig. 26. Distribution of $I_{\text {geo }}$ for $\mathrm{Hg}$ in surficial soil.

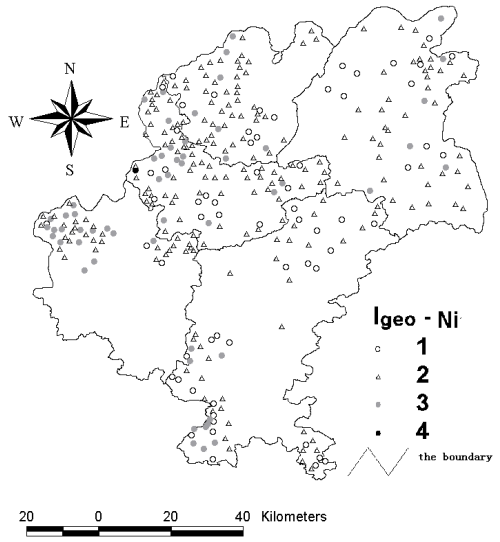

Fig. 27. Distribution of $I_{\text {geo }}$ for $\mathrm{Ni}$ in surficial soil.

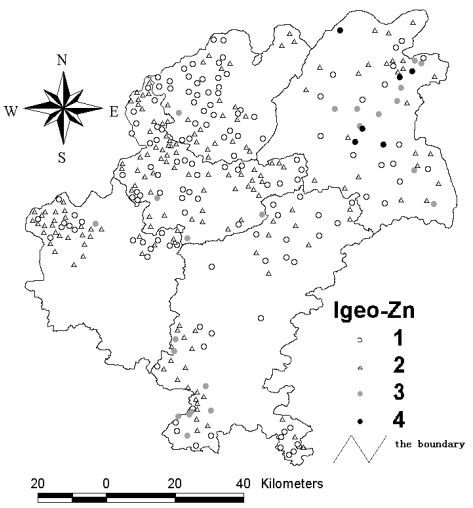

Fig. 28. Distribution of $I_{\text {geo }}$ for $\mathrm{Zn}$ in surficial soil. 


\subsubsection{Contamination degree analysis of heavy metals in surficial soil}

Contamination Degree (CD) was the most intuitive and commonly used one of the parameters for evaluating heavy metals pollution. The parameter represented the content of heavy metals in soil was over the national standard, and it was expressed as shown.

$$
\mathrm{CD}=\frac{c_{i}}{c_{A}}-1
$$

$C_{\mathrm{i}}$ represents the analysis value in i sample of an element (the concentration of an element in sample). $C_{\mathrm{A}}$ means the maximum limit of the element concentration in environment, which was commonly the Quality Standard of Soil Environment. The primary standard of national quality standard in soil environment (GB15618-1995) was used to calculate the heavy metals pollution degree for $\mathrm{C}_{\mathrm{A}}$.

The contamination degrees of heavy metals in surficial soil of Guiyang city were analyzed (Table 4 to Table 11). The results indicated that the maximum of arsenic contaminative degree of surficial soil in Guiyang is 4.27. 50.2 per cent surficial soil did not suffer the pollution. The contaminative degree in 97 per cent surficial soil in Guiyang is smaller than 2 and the total contaminative degree is slightly over zero. So the surficial soil of Guiyang suffers the slight pollution. Of cadmium are 12.1. 57.9 per cent surficial soil did not suffer the pollution. 96 per cent is smaller than 4 and the total is over zero. So suffers pollution of Cd. Of chromium are 2.01. 69 per cent did not suffer the pollution, 30.6per cent slight pollution. The total is less than zero. So not suffer pollution of Cr. Of copper are 5.09. 53.2 per cent did not suffer the pollution. The total is slightly over zero. So suffers slight pollution of $\mathrm{Cu}$. Of lead are 8.11. 49.9 per cent did not suffer the pollution. The total is slightly over zero. So suffers slight pollution of $\mathrm{Pb}$. Of mercury are 45.87. 56.1 per cent did not suffer the pollution. The total is over zero. So suffers pollution of $\mathrm{Hg}$. Of nickel is 1.56. 64 per cent did not suffer the pollution. The total is less than zero. So not suffer pollution of Ni. Of zinc are 2.85. 77.8 per cent did not suffer the pollution. The total is less than zero. So not suffer pollution of $\mathrm{Zn}$. Consideration the pollution to join with 8 kinds of heavy metals, 40.2 per cent have no contamination of heavy metal, 15 per cent from no pollution to slight pollution, 36.1 per cent slightly pollution, 7.2 per cent mid-pollution, 1.4 per cent serious pollution in the surficial soil of Guiyang.

\begin{tabular}{llll}
\hline $\mathrm{CD}_{\mathrm{As}}$ & $\mathrm{x} \leq 0$ & $0<\mathrm{x} \leq 1$ & $1<\mathrm{x} \leq 2$ \\
\hline Number & 244 & 187 & 42 \\
Ratio & $50.2 \%$ & $38.5 \%$ & $8.6 \%$ \\
$\mathrm{CD}_{\text {As }}$ & $2<\mathrm{x} \leq 3$ & $3<\mathrm{x} \leq 4$ & $\mathrm{x}>4$ \\
Number & 6 & 4 & 3 \\
Ratio & $1.2 \%$ & $0.8 \%$ & $0.6 \%$
\end{tabular}

Note: Average: 0.206; Min:-0.81; Max: 4.27

Table 4. The contamination degree on As in surficial soil of Guiyang city. 


\begin{tabular}{|c|c|c|c|c|}
\hline $\mathrm{CD}_{\mathrm{Cd}}$ & $x \leq 0$ & $0<x \leq 1$ & $1<x \leq 2$ & $2<x \leq 3$ \\
\hline Number & 282 & 72 & 48 & 42 \\
\hline Ratio & $57.9 \%$ & $14.8 \%$ & $9.9 \%$ & $8.6 \%$ \\
\hline $\mathrm{CD}_{\mathrm{Cd}}$ & $\begin{array}{l}3< \\
x \leq 4\end{array}$ & $4<x \leq 5$ & $5<x \leq 6$ & $x>6$ \\
\hline Number & 22 & 7 & 5 & 9 \\
\hline Ratio & $4.5 \%$ & $1.4 \%$ & $1.0 \%$ & $1.9 \%$ \\
\hline \multicolumn{5}{|c|}{ Note: Average:0.51; Min:-0.995; Max:12.1 } \\
\hline
\end{tabular}

Table 5. The contamination degree on Cd in surficial soil of Guiyang city.

\begin{tabular}{llcl}
\hline $\mathrm{CD}_{\mathrm{Cr}}$ & $\leq 0$ & $0<\mathrm{x} \leq 0.5$ & $0.5<\mathrm{x} \leq 1$ \\
\hline Number & 337 & 118 & 24 \\
Ratio & $69.2 \%$ & $24.3 \%$ & $4.9 \%$ \\
$\mathrm{CDCr}$ & $1<\mathrm{x} \leq 1.5$ & $\mathrm{x}>1.5$ & \\
Number & 7 & 1 & \\
Ratio & $1.4 \%$ & $0.2 \%$ & \\
\multicolumn{4}{l}{ Note:Average:-0.16;Min:-0.92; Max:2.01 }
\end{tabular}

Table 6. The contamination degree on $\mathrm{Cr}$ in surficial soil of Guiyang city.

\begin{tabular}{llll}
\hline $\mathrm{CD}_{\mathrm{Cu}}$ & $\leq 0$ & $0<\mathrm{x} \leq 1$ & $1<\mathrm{x} \leq 2$ \\
\hline Number & 177 & 99 & 43 \\
Ratio & $53.2 \%$ & $29.7 \%$ & $12.9 \%$ \\
$\mathrm{CD}_{\mathrm{Cu}}$ & $2<\mathrm{x} \leq 3$ & \multicolumn{2}{c}{$\mathrm{x}>3$} \\
Number & 11 & \multicolumn{2}{c}{3} \\
Ratio & $3.3 \%$ & \multicolumn{2}{c}{$0.9 \%$} \\
Note: Average:0.23; Min:-0.94; Max:5.09
\end{tabular}

Table 7. The contamination degree on $\mathrm{Cu}$ in surficial soil of Guiyang city.

\begin{tabular}{llll}
\hline $\mathrm{CD}_{\mathrm{Pb}}$ & $\leq 0$ & $0<\mathrm{x} \leq 1$ & $1<\mathrm{x} \leq 2$ \\
\hline Number & 243 & 189 & 37 \\
Ratio & $49.90 \%$ & $38.80 \%$ & $7.60 \%$ \\
$\mathrm{CD}_{\mathrm{Pb}}$ & $2<\mathrm{x} \leq 3$ & $3<\mathrm{x} \leq 4$ & $\mathrm{x}>4$ \\
Number & 7 & 8 & 3 \\
Ratio & $1.50 \%$ & $1.60 \%$ & $0.60 \%$ \\
\multicolumn{4}{l}{ Note:Average:0.23;Min:-0.98; Max:8.11 } \\
\hline
\end{tabular}

Table 8. The contamination degree on $\mathrm{Pb}$ in surficial soil of Guiyang city. 


\begin{tabular}{ccccc}
\hline $\mathrm{CD}_{\mathrm{Hg}}$ & $\leq 0$ & $0<\mathrm{x} \leq 1$ & $1<\mathrm{x} \leq 2$ & $2<\mathrm{x} \leq 3$ \\
\hline Number & 273 & 155 & 33 & 10 \\
Ratio & $56.1 \%$ & $31.8 \%$ & $6.8 \%$ & $2.1 \%$ \\
$\mathrm{CD}_{\mathrm{HG}}$ & $3<\mathrm{x} \leq 4$ & $4<\mathrm{x} \leq 5$ & $\mathrm{x}>5$ \\
Number & 6 & 1 & 9 \\
Ratio & $1.2 \%$ & $0.2 \%$ & $1.8 \%$ \\
Note: Average:0.48; Min:-0.93; Max:45.87
\end{tabular}

Table 9. The contamination degree onHg in surficial soil of Guiyang city.

\begin{tabular}{cccc}
\hline $\mathrm{CD}_{\mathrm{Ni}}$ & $\leq 0$ & $0<\mathrm{x} \leq 0.5$ & $0.5<\mathrm{x} \leq 1$ \\
Number & 213 & 88 & 27 \\
Ratio & $64.0 \%$ & $26.4 \%$ & $8.1 \%$ \\
$\mathrm{CD}_{\mathrm{Ni}}$ & $1<\mathrm{x} \leq 1.5$ & $\mathrm{x}>1.5$ \\
Number & 4 & 1 \\
Ratio & $1.2 \%$ & $0.3 \%$ \\
\multicolumn{4}{l}{ Note: Average :-0.04; Min:-0.77; Max:1.56 }
\end{tabular}

Table 10. The contamination degree on Ni in surficial soil of Guiyang city.

\begin{tabular}{ccccc}
\hline $\mathrm{CD}_{\mathrm{Zn}}$ & $\leq 0$ & $0<\mathrm{x} \leq 0.5$ & $0.5<\mathrm{x} \leq 1$ & $1<\mathrm{x} \leq 1.5$ \\
Number & 259 & 52 & 11 & 5 \\
Ratio & $77.8 \%$ & $15.6 \%$ & $3.3 \%$ & $1.5 \%$ \\
$\mathrm{CD}_{\mathrm{Zn}}$ & $1.5<\mathrm{x} \leq 2$ & $2<\mathrm{x} \leq 2.5$ & $\mathrm{x}>2.5$ \\
Number & 2 & 2 & 2 \\
Ratio & $0.6 \%$ & $0.6 \%$ & $0.6 \%$ \\
\multicolumn{4}{l}{ Note: Average:-0.15; Min:-1.00; Max:2.85 } \\
\hline
\end{tabular}

Table 11. The contamination degree on $\mathrm{Zn}$ in surficial soil of Guiyang city.

\subsubsection{The correlation of heavy metal elements in surficial soil}

The correlation of heavy metals were analyzed and twin-elements that correlation coefficient reached extremely significant level $(\mathrm{P}<0.01)$ were $\mathrm{As}-\mathrm{Pb}, \mathrm{Cd}-\mathrm{Cr}, \mathrm{Ni}-\mathrm{Cd}, \mathrm{Cu}-$ $\mathrm{Cr}, \mathrm{Cr}-\mathrm{Ni}, \mathrm{Cr}-\mathrm{Zn}, \mathrm{Cu}-\mathrm{Ni}, \mathrm{Cu}-\mathrm{Pb}, \mathrm{Cu}-\mathrm{Zn}, \mathrm{Ni}-\mathrm{Zn}, \mathrm{Pb}-\mathrm{Zn}$, the twin-elements which correlation was $\mathrm{P}<0.05$ were $\mathrm{As}-\mathrm{Zn}, \mathrm{Cd}-\mathrm{Hg}, \mathrm{Cd}-\mathrm{Zn}, \mathrm{Pb}-\mathrm{Ni}$ by using SPSS16.0 with $\mathrm{CA}($ Table 12).The correlation between heavy metals mainly because of heavy metal elements between parent rocks associated. For example, the correlation of metalloid element As and $\mathrm{Pb}$ reached extremely significant level, of $\mathrm{As}$ and $\mathrm{Zn}$ reached significant level, for As ore often associated in the sulfide mineral of $\mathrm{Pb}$ and $\mathrm{Zn}$, and were produced together with other minerals such as pyrite and sphalerite. The content of As was less than $5-10000 \mathrm{mg} / \mathrm{kg}$ in the galena, abnormal area were formed when As were released in the ore mining and smelting 
(Liao Z J, 1992). Pb-Zn deposits were mainly distributed in the northeast area, northwest area, south-central area and southwest area (Xu H N and Xu J 1, 1996). As and its compound were often accompanied in the non-ferrous metal and precious metal ore, arsenide was distributed in the kinds of intermediate product (Li Q and Mo D L, 1997). The correlation of $\mathrm{Cd}$ and $\mathrm{Zn}$ reached significant, because there was no separate $\mathrm{Cd}$ ore, $\mathrm{Cd}$ was often accompanied with $\mathrm{Zn}$ ore, $\mathrm{Cd}$ was generally existed in the $\mathrm{Zn}$ ore as the forms of $\mathrm{CdS}$ and $\mathrm{CdCO}_{3}$, and the concentration of $\mathrm{Cd}$ was between $0.01 \%$ and $0.5 \%$.

\begin{tabular}{|c|c|c|c|c|c|c|c|c|}
\hline & As & $\mathrm{Cd}$ & $\mathrm{Cr}$ & $\mathrm{Cu}$ & $\mathrm{Hg}$ & $\mathrm{Ni}$ & $\mathrm{Pb}$ & $\mathrm{Zn}$ \\
\hline As & 1 & & & & & & $\begin{array}{c}* \\
(+)\end{array}$ & $\begin{array}{c}* \\
(+)\end{array}$ \\
\hline $\mathrm{Cd}$ & & 1 & $\begin{array}{c}* * \\
(-)\end{array}$ & & $\begin{array}{c}* \\
(+)\end{array}$ & $\begin{array}{l}* * \\
(+)\end{array}$ & & ${ }^{*}(-)$ \\
\hline $\mathrm{Cr}$ & & & 1 & $\begin{array}{c}* * \\
(+)\end{array}$ & & $\begin{array}{c}* * \\
(+)\end{array}$ & & $\begin{array}{l}* * \\
(+)\end{array}$ \\
\hline $\mathrm{Cu}$ & & & & 1 & & $\begin{array}{c}* * \\
(+)\end{array}$ & $\begin{array}{c}* * \\
(-)\end{array}$ & $\begin{array}{c}* * \\
(+)\end{array}$ \\
\hline $\mathrm{Hg}$ & & & & & 1 & & & \\
\hline $\mathrm{Ni}$ & & & & & & 1 & $\begin{array}{c}* \\
(-)\end{array}$ & $\begin{array}{l}* * \\
(+)\end{array}$ \\
\hline $\mathrm{Pb}$ & & & & & & & 1 & $\begin{array}{l}* * \\
(+)\end{array}$ \\
\hline $\mathrm{Zn}$ & & & & & & & & 1 \\
\hline
\end{tabular}

*: significant level $(\mathrm{P}<0.05)$; **: extremely significant level $(\mathrm{P}<0.01)$;

$(+)$ : positive correlation; $(-)$ : negative correlation

Table 12. The relativities between contaminating elements in surficial soil of Guiyang.

\subsubsection{The influences of soil types in heavy metals pollution}

On the basis of measured values in the different characteristics of soil types on heavy metals in surficial soils, the space isoline map and soil type distribution map of Guiyang City were overlaid by using the software ArcView 3.2. The different level concentrations of heavy metals were statistical analyzed according to the different soil types. Meanwhile, to facilitate analysis, , soil types within the study area were divided into three types by human impact: man-influenced soil type, soil type by human impact in general and soil type with less human impact.

\subsubsection{Soils types with stronger human impact: Yellow earths, limestone soils, paddy soils}

Yellow soil lands an area of $3.335 \times 10^{5}$ ha for the area of Guiyang City it totally lands $41.5 \%$ land area of Guiyang City. Yellow was born in hot and humid environmental conditions, rock weathering and fast weathering by strong leaching, base captions and silicon ions have leached, clay and the formation of secondary minerals constantly, ferric oxide relative aggregation, in which iron oxide by strong hydration, the formation of high water content of goethite $\left(\mathrm{Fe}_{2} \mathrm{O} \cdot \mathrm{H}_{2} \mathrm{O}\right)$, limonite $\left(\mathrm{Fe}_{2} \mathrm{O}_{3} \cdot 2 \mathrm{H}_{2} \mathrm{O}\right)$, more water, iron oxide $\left(\mathrm{Fe}_{2} \mathrm{O} .3 \mathrm{H}_{2} \mathrm{O}\right)$, the 
yellow hue of the minerals is the main hue(Sun,2002). Lime area $2.021 \times 10^{5}$ ha, accounting for land area of Guiyang City, 25.2\%. Guiyang Karst landforms, carbonate rocks are widely distributed, accounting for $80.63 \%$ area of Guiyang City, the corrosion - erosion, the erosion severe cases, the carbonate rocks exposed, weathering and limestone soil. Corrosion of carbonate karst weathering process is the release of Ca leaching, the residual calcium carbonate and clay minerals into the soil formed by the lime soil, shallow soil, and more with rock debris, soil properties affected by litho logy great, are rock soil. Limestone soil, with the abundant calcium and substitution of base level is high, the leaching process, due to constantly add calcium carbonate to the soil base to be preserved, weathering alteration of other minerals are also weak, delayed Al-rich off the role of silicon occur so long in a juvenile state. Distribution of lime in the soil and the soil zone boundaries clearly.

Paddy area is $1.156 \times 10^{5} \mathrm{ha}$, accounting for the total land area of Guiyang City, $14.40 \%$. In dam and hills in the valley bottom of the groove, light and heat conditions are good, as the irrigation and drainage conditions are good, the piece of the paddy field in the long-term hydroponics are the formation of the hydromorphic paddy soils that was the advanced stage of development of the paddy soil. As the periodic irrigation and drying, the soil, reduction and oxidation in alternating, the soil of iron, manganese and substances to restore migration, oxidative deposition, mind patterns of soil to form a brown rust, rust, and prismlike structure, which is a typical paddy soil types, is the main farming soil in Guiyang. The development at the initial stage of paddy rice soil infiltration education, are located in higher ground water table is low, almost no groundwater impact position. In the artificial irrigation, the irrigation of the soil affected by seasonal, alternating reduction and oxidation process, iron, manganese and base material was transported, deposited, in the former home territory, based on the formation of more than $20 \mathrm{~cm}$ percogenic layer, initially with the characteristics of paddy soil. At the same time as soil pollution is not serious.

It shows that the levels of heavy metals were distributed at different levels, but mostly the first level and second level from Table 13 to Table 15.These three categories of soil type are the major soil types in Guiyang. By densely constraints, these three main soil types are local residents using the soil type. Yellow soil that the layer of soil and humus are thicker and soil acidity as well is the top soil for building timber forest and tea orchard. And its natural environment in which conditions is good, so it was open to most of the yellow land. Lime soil with high organic matter content, neutral to slightly alkaline, but the soil is thin, easy to dry; paddy soil water and heat conditions are better in the land after long-term aging and the formation of farming. In the long-term cultivation in the maturation process, human activities on soil heavy metal content of more. Therefore, the heavy metals content in different levels will have the distribution, while not a serious problem due to soil contamination, so in the first level and second level of the majority.

\begin{tabular}{cccccccc}
\hline & $\mathrm{Cd}$ & $\mathrm{Cr}$ & $\mathrm{Cu}$ & $\mathrm{Hg}$ & $\mathrm{Ni}$ & $\mathrm{Pb}$ & $\mathrm{Zn}$ \\
\hline 1'th level & 73.2 & 20.2 & 74.2 & 96.7 & 37.2 & 63.7 & 68.4 \\
2 $^{\text {th level }}$ & 21.1 & 61.1 & 18.9 & 1.5 & 45.4 & 29.0 & 23.4 \\
3 $^{\text {th }}$ level & 3.7 & 16.5 & 4.1 & 0.5 & 12.3 & 4.8 & 4.6 \\
4 $^{\text {th level }}$ & 1.4 & 1.9 & 1.8 & 0.3 & 4.0 & 1.7 & 1.7 \\
5 $^{\text {th level }}$ & 0.4 & 0.3 & 0.5 & 0.2 & 0.8 & 0.5 & 1.9 \\
6 $^{\text {th }}$ level & 0.2 & 0.0 & 0.5 & 0.8 & 0.3 & 0.3 & 0 \\
\hline
\end{tabular}

Table 13. The percentage (\%) of different concentration levels of heavy metals in Yellow earths of Guiyang. 


\begin{tabular}{cccccccc}
\hline & $\mathrm{Cd}$ & $\mathrm{Cr}$ & $\mathrm{Cu}$ & $\mathrm{Hg}$ & $\mathrm{Ni}$ & $\mathrm{Pb}$ & $\mathrm{Zn}$ \\
\hline $1^{\text {th }}$ level & 61.2 & 30.4 & 70.3 & 97 & 38.4 & 69.2 & 73.8 \\
$2^{\text {th }}$ level & 31.9 & 51.1 & 20.8 & 2.0 & 37.7 & 26.6 & 20.4 \\
$3^{\text {th }}$ level & 4.8 & 13.4 & 5.8 & 0.4 & 13.3 & 2.9 & 5.1 \\
$4^{\text {th }}$ level & 1.1 & 4.6 & 2.7 & 0.3 & 6.9 & 1 & 0.5 \\
$5^{\text {th }}$ level & 0.5 & 0.4 & 0.4 & 0.2 & 3.3 & 0.1 & 0.2 \\
6 $^{\text {th }}$ level & 0.5 & 0.1 & 0 & 0.1 & 0.4 & 0.2 & 0 \\
\hline
\end{tabular}

Table 14. The percentage (\%) of different concentration levels of heavy metals in Limestone soils of Guiyang.

\begin{tabular}{lccccccc}
\hline & $\mathrm{Cd}$ & $\mathrm{Cr}$ & $\mathrm{Cu}$ & $\mathrm{Hg}$ & $\mathrm{Ni}$ & $\mathrm{Pb}$ & $\mathrm{Zn}$ \\
\hline $1^{\text {th }}$ level & 69.6 & 22.6 & 74.2 & 96.8 & 40 & 68.3 & 72.6 \\
$2^{\text {th }}$ level & 21.7 & 58.2 & 17.4 & 2.3 & 39.9 & 28.1 & 18.1 \\
3 $^{\text {th }}$ level & 6.3 & 16.7 & 4.9 & 0.4 & 13.7 & 2.6 & 6.5 \\
$4^{\text {th }}$ level & 1.6 & 2 & 1.5 & 0.4 & 4.7 & 0.8 & 1.5 \\
$5^{\text {th }}$ level & 0.3 & 0.5 & 1.5 & 0.1 & 1 & 0.1 & 1.3 \\
6th level $^{\text {th }}$ & 0.5 & 0 & 0.5 & 0 & 0.7 & 0.1 & 0 \\
\hline
\end{tabular}

Table 15. The percentage (\%) of different concentration levels of heavy metals in Paddy soils of Guiyang.

\subsubsection{Soils types with common human impact: Skeleton soils, purplish soils, litho soils, yellow-brown earths}

Thick bone was $1.015 \times 10^{5}$ ha of $12.64 \%$ total land area in Guiyang city. Thick bone parent rocks were the weathering slope and residual consisting of shale and sand-shale. The soil body of soil type was instability, developed badly, thin soil and serious soil erosion. Phosphorus, potassium content is low. Purple soil area 104 ha, Guiyang 1.20 land area of $1.9 \%$. Purple soil are mainly Jurassic purple red sandstone and mudstone tertiary surface soil after a. Purple rock type soft and crunchy, physical weathering speed, soil erosion is fast. And constantly weathering has added to make purple soil in the early stage of longterm. Purple clay mineral grains by weathering, silicon, carbonate etc iron compounds to form complex was stable in surface film, delaying the chemical weathering, keep the minerals of iron ore, the properties of soil siderite, thus presents. The rock soil due to constantly weathering of supplement, natural fertility soil of natural vegetation, also grew thick.

It can be seen in the heavy metals element content level mainly focus on four levels from Table 16 to Table 19. These four types of soil or natural conditions, using value is not high, Either the area is small, but the natural conditions, so the natural vegetation, soil for use, so not easily by the four types of human influence, but also affect the three types of great influence. Therefore, the four kinds of soil heavy metal content mainly concentrated in the top four. 


\begin{tabular}{cccccccc}
\hline & $\mathrm{Cd}$ & $\mathrm{Cr}$ & $\mathrm{Cu}$ & $\mathrm{Hg}$ & $\mathrm{Ni}$ & $\mathrm{Pb}$ & $\mathrm{Zn}$ \\
\hline $1^{\text {th level }}$ & 71.2 & 28.3 & 67.0 & 96 & 44.5 & 68 & 72.2 \\
$2^{\text {th level }}$ & 24.6 & 43.8 & 21.2 & 3.7 & 34.3 & 31.8 & 21.2 \\
$3^{\text {th }}$ level & 3.8 & 25.3 & 6.0 & 0.1 & 12.3 & 0.2 & 6.6 \\
$4^{\text {th }}$ level & 0.4 & 2.6 & 3.9 & 0.1 & 8.1 & 0 & 0 \\
$5^{\text {th }}$ level & 0 & 0 & 1.7 & 0 & 0.8 & 0 & 0 \\
$6^{\text {th }}$ level & 0 & 0 & 0.2 & 0.1 & 0 & 0 & 0 \\
\hline
\end{tabular}

Table 16. The percentage (\%) of different concentration levels of heavy metals in Skeletol soils.

\begin{tabular}{llllllll}
\hline & $\mathrm{Cd}$ & $\mathrm{Cr}$ & $\mathrm{Cu}$ & $\mathrm{Hg}$ & $\mathrm{Ni}$ & $\mathrm{Pb}$ & $\mathrm{Zn}$ \\
\hline $1^{\text {th }}$ level & 68.3 & 21.1 & 87.5 & 91.4 & 41.8 & 78.1 & 68.6 \\
$2^{\text {th }}$ level & 22.3 & 67.1 & 10.1 & 6.6 & 42.2 & 15.8 & 26.2 \\
$3^{\text {th }}$ level & 7.5 & 9.9 & 1.1 & 0.7 & 8.2 & 4.7 & 4.8 \\
$4^{\text {th }}$ level & 1.9 & 1.9 & 1.3 & 0.7 & 2.5 & 1.4 & 0.4 \\
$5^{\text {th }}$ level & 0 & 0 & 0 & 0.6 & 4.3 & 0 & 0 \\
$6^{\text {th }}$ level & 0 & 0 & 0 & 0 & 1.0 & 0 & 0 \\
\hline
\end{tabular}

Table 17. The percentage (\%) of different concentration levels of heavy metals in Purplish soils.

\begin{tabular}{llllllll}
\hline & $\mathrm{Cd}$ & $\mathrm{Cr}$ & $\mathrm{Cu}$ & $\mathrm{Hg}$ & $\mathrm{Ni}$ & $\mathrm{Pb}$ & $\mathrm{Zn}$ \\
\hline 1 $^{\text {th level }}$ & 51.3 & 37.7 & 51.4 & 98.9 & 21.4 & 78.5 & 66.0 \\
$2^{\text {th level }}$ & 39.3 & 38.0 & 33.1 & 1.1 & 42.7 & 18.5 & 30.6 \\
$3^{\text {th }}$ level & 7.8 & 11.4 & 11.1 & 0 & 16.9 & 1.4 & 3.2 \\
$4^{\text {th level }}$ & 1.5 & 7.0 & 4.4 & 0 & 6.2 & 1.6 & 0.2 \\
$5^{\text {th }}$ level & 0.1 & 5.6 & 0 & 0 & 5.1 & 0 & 0 \\
$6^{\text {th }}$ level & 0 & 0.3 & 0 & 0 & 7.7 & 0 & 0 \\
\hline
\end{tabular}

Table 18. The percentage (\%) of different concentration levels of heavy metals in Litho soils.

\begin{tabular}{llllllll}
\hline & $\mathrm{Cd}$ & $\mathrm{Cr}$ & $\mathrm{Cu}$ & $\mathrm{Hg}$ & $\mathrm{Ni}$ & $\mathrm{Pb}$ & $\mathrm{Zn}$ \\
\hline $1^{\text {th }}$ level & 52.3 & 28.5 & 90.0 & 79.3 & 45.2 & 41.7 & 78.6 \\
$2^{\text {th }}$ level & 42.8 & 71.1 & 10.0 & 13.8 & 41.5 & 21.0 & 16.7 \\
$3^{\text {th }}$ level & 4.9 & 0.4 & 0 & 3.1 & 7.3 & 25.1 & 0.7 \\
$4^{\text {th }}$ level & 0 & 0 & 0 & 2.2 & 2.7 & 10.3 & 1.4 \\
5 $^{\text {th }}$ level & 0 & 0 & 0 & 1.3 & 3.3 & 0.4 & 2.6 \\
$6^{\text {th level }}$ & 0 & 0 & 0 & 0.3 & 0 & 1.5 & 0 \\
\hline
\end{tabular}

Table 19. The percentage (\%) of different concentration levels of heavy metals in Yellowbrown earths.

\subsubsection{Soils types with less human impact: Mountain meadow soils and bog soils}

In Guiyang City, The area of the Bog soils is $902 \mathrm{ha}$, accounting for $0.11 \%$ of the total. On the surface of the local ground of the plateau, peal coal was formed by the accumulation of wet plants in the ancient swamp. Crustal movement in the later, ground up-list, swamp marsh 
broke off marsh gradually, black peat accumulated, the lower layers was white washing, which is the current peat.

Mountain meadow soil $379 \mathrm{ha}$, accounting only $0.05 \%$ of land area of Guiyang. Mountain meadow soil is within the forest line, the gentle mountain top hi wet meadow and meadow shrub coppice Semis formed a class of soil. Such thin layers of soil, and generally contain gravel, grass surface layer with.

As shown in Table 20 to Table 21,the content of heavy metals in these two soil types are mainly concentrated in a Single interval, this phenomenon may be related to less human impact (such as fertilizer), heavy metals content in these soil types are mainly concentrated in the range corresponding their baseline values.

\begin{tabular}{cccccccc}
\hline & $\mathrm{Cd}$ & $\mathrm{Cr}$ & $\mathrm{Cu}$ & $\mathrm{Hg}$ & $\mathrm{Ni}$ & $\mathrm{Pb}$ & $\mathrm{Zn}$ \\
\hline $1^{\text {th }}$ level & 0 & 16.8 & 100 & 0 & 100 & 0 & 100 \\
$2^{\text {th }}$ level & 100 & 83.2 & 0 & 100 & 0 & 0 & 0 \\
$3^{\text {th }}$ level & 0 & 0 & 0 & 0 & 0 & 17.4 & 0 \\
$4^{\text {th }}$ level & 0 & 0 & 0 & 0 & 0 & 82.6 & 0 \\
$5^{\text {th }}$ level & 0 & 0 & 0 & 0 & 0 & 0 & 0 \\
$6^{\text {th }}$ level & 0 & 0 & 0 & 0 & 0 & 0 & 0 \\
\hline
\end{tabular}

Table 20. The percentage (\%) of different concentration levels of heavy metals in Bog soils.

\begin{tabular}{cccccccc}
\hline & $\mathrm{Cd}$ & $\mathrm{Cr}$ & $\mathrm{Cu}$ & $\mathrm{Hg}$ & $\mathrm{Ni}$ & $\mathrm{Pb}$ & $\mathrm{Zn}$ \\
\hline $1^{\text {th }}$ level & 100 & 65.8 & 98.2 & 100 & 0 & 0 & 100 \\
$2^{\text {th level }}$ & 0 & 34.2 & 1.8 & 0 & 100 & 100 & 0 \\
$3^{\text {th }}$ level & 0 & 0 & 0 & 0 & 0 & 0 & 0 \\
$4^{\text {th }}$ level & 0 & 0 & 0 & 0 & 0 & 0 & 0 \\
$5^{\text {th }}$ level & 0 & 0 & 0 & 0 & 0 & 0 & 0 \\
$6^{\text {th }}$ level & 0 & 0 & 0 & 0 & 0 & 0 & 0 \\
\hline
\end{tabular}

Table 21. The percentage (\%) of different concentration levels of heavy metals in Meadow solonchaks.

\section{Conclusions}

1. The mean value, standard deviation and maximum of As separately are $18.09 \mathrm{mg} / \mathrm{kg}$, $11.57 \mathrm{mg} / \mathrm{kg}$ and $79.30 \mathrm{mg} / \mathrm{kg}$ in the surficial soil in Guiyang, of Cd separately are $0.302 \mathrm{mg} / \mathrm{kg}, 0.363 \mathrm{mg} / \mathrm{kg}, 2.620 \mathrm{mg} / \mathrm{kg}$ and 95.7 percent smaller than $1.000 \mathrm{mg} / \mathrm{kg}$., of Cu separately are $43.1 \mathrm{mg} / \mathrm{kg}, 30.3 \mathrm{mg} / \mathrm{kg}, 213.0 \mathrm{mg} / \mathrm{kg}$ and 94.6 percent smaller than $100.0 \mathrm{mg} / \mathrm{kg}$, of $\mathrm{Pb}$ are $43.2 \mathrm{mg} / \mathrm{kg}, 31.3 \mathrm{mg} / \mathrm{kg}, 318.9 \mathrm{mg} / \mathrm{kg}$ and 95.5 per cent smaller than $100.0 \mathrm{mg} / \mathrm{kg}$, of $\mathrm{Hg}$ are $0.222 \mathrm{mg} / \mathrm{kg}, 0.531 \mathrm{mg} / \mathrm{kg}, 7.030 \mathrm{mg} / \mathrm{kg}$ and 98.2 smaller 
than $1.000 \mathrm{mg} / \mathrm{kg}$, of $\mathrm{Ni}$ are $38.3 \mathrm{mg} / \mathrm{kg}, 14.9 \mathrm{mg} / \mathrm{kg}, 102.5 \mathrm{mg} / \mathrm{kg}$ and 95.8 percent smaller than $70.0 \mathrm{mg} / \mathrm{kg}$, of $\mathrm{Zn}$ are $84.7 \mathrm{mg} / \mathrm{kg}, 49.8 \mathrm{mg} / \mathrm{kg}, 385.0 \mathrm{mg} / \mathrm{kg}$ and 94.3 percent smaller than $150.0 \mathrm{mg} / \mathrm{kg}$.

2. Comprehensively considering the results of calculation using the two kinds of methods, we respectively take $9.04 \mathrm{mg} / \mathrm{kg}, 0.068 \mathrm{mg} / \mathrm{kg}, 18.8 \mathrm{mg} / \mathrm{kg}, 46.3 \mathrm{mg} / \mathrm{kg}, 14.8 \mathrm{mg} / \mathrm{kg}$, $0.045 \mathrm{mg} / \mathrm{kg}, 44.0 \mathrm{mg} / \mathrm{kg}, 17.0 \mathrm{mg} / \mathrm{kg}$ as the baseline values of $\mathrm{As}, \mathrm{Cd}, \mathrm{Cu}, \mathrm{Zn}, \mathrm{Pb}, \mathrm{Hg}$, $\mathrm{Cr}$ and $\mathrm{Ni}$ in topsoil of Guiyang.

3. By the results of Geo-accumulation analysis of heavy metals in surficial soil, we get the surficial soil in 41 per cent of the Guiyang did not suffer the arsenic contaminative, In 40 per cent did not suffer the cadmium contaminative, In 46 per cent did not suffer the chromium contaminative, In 38 per cent did not suffer the copper contaminative, In 18 per cent did not suffer the lead contaminative, In 12 per cent did not suffer the mercury contaminative, In 19.2 per cent did not suffer the nickel contaminative.

4. By the results of contamination degree analysis, the maximum of arsenic contaminative degree of surficial soil in Guiyang is 4.27. Of cadmium are 12.1. Of chromium are 2.01. Of copper are 5.09. Of lead are 8.11. Of mercury are 45.87. Of nickel is 1.56. Of zinc are 2.85 .

5. The soil types in this area were divided into three types of soil by the human impact degree. The three soil types of yellow soil, limestone soil and paddy soil that were the main soil types in Guiyang city were greatly influenced by human. The four soil types of skeleton soil, purple soil, stone soil and yellow brown soil that were not easily used were certainly influenced by human, the concentration of heavy metals in boggy soil and mountain meadow soil were concentrated on an interval, and tow types of soil (boggy soil and mountain meadow soil) were less influenced by human.

\section{References}

[1] Bauer I. and Bor J.1993.Vertikale Bilanzierung von Schwermetallen in Boden Kennzeichning der Empfinndlichkeit der boden gegenuber Schwermetallen unter Berucksichtigung von lithogenem Grundgehalt, pedogener An - und Abreicherung some antheopogener Zusatzbelastung, Teil 2. Texte56, Umweltbundesam, Berlin.

[2] Bauer I. and Bor J.1995.Lithogene, geonene und anthropogene Schwermetallgehalte von Lobboden an den Beispielen von $\mathrm{Cu}, \mathrm{Zn}, \mathrm{Ni}, \mathrm{Pb}, \mathrm{Hg}$ und $\mathrm{Cd}[\mathrm{J}]$. Mainzer Geowiss Mit. 24, 47-70

[3] Bauer I., Spernger M. and Bor J.1992.Die Berechnung Lithogener und geonerer Schwermetallgehalte von Lobboden am Beispielen von $\mathrm{Cu}, \mathrm{Zn}$ und $\mathrm{Pb}[\mathrm{J}]$. Mainzer Geowiss Mitt. 21, 47-70

[4] Chen Cuihua, Ni Shijun, He Binbin, et al.,2008. Spatial-temporal variation of heavy metals contamination in sediments of the dexing mine, Jiangxi province[J]. Acta Geoscientica Sinica,29(5):639-646

[5] Chen Hangxin, Shen Xiachu, Yan Guangsheng. 1998. Research of experimental unit about international geochemical mapping. Edited by Wang Yanjun[M]. In The Geochemical paper of the 30th international geological meeting. Geological Press. Beijing, China.57-75

[6] Darnley A G, 1997. A global geochemical reference network: the foundation for geochemical baselines. J Geochemistry Exploration, 60(1):1-5 
[7] Forstner U, Muller G. 1981.Concentrations of heavy metals and polycyclic aromatic hycarbons in river sediments: geochemical background, man's influence and environmental impact[J]. Geojournal, 5: 417 432.

[8] Forstner U, Ahlf W, Calmano W, et al. 1990.Sediment criteria development-contributions from environmental geochemistry to water quality management[A]. In: Heling D, Rothe P, Forstner U, et al. Sediments and environmental geochemistry: selected aspects and case histories[C]. Berlin Heidelberg:Springer-Verlag, 311 338.

[9] $\mathrm{Hu}$ Mianhao.2010. Application of index of geo-accumulation in evaluation of heavy metals pollution in Municipal sludge from Nanchang[J]. Guangdong Weiliang Yuansu Kexue,17(3):

[10] National Environmental Protect Bureau of China, National Technology Supervise Bureau of China.1995. GB15618-1995 Environmental Quality Standard for Soil [S].Beijing: Environmental Sciences Press of China(in Chinese)

[11] National Environmental Protect Bureau of China and National Technology Supervise Bureau of China.1998.GB/T17134-1997. Environmental Quality Determination of total arsenic-the silver diethyl dithiocarbamate photometric method[S]. Beijing: Environmental Sciences Press of China(in Chinese)

[12] National Environmental Protect Bureau of China and National Technology Supervise Bureau of China.1998.GB/T17136-1997. Environmental Quality Determination of total mercury-cold atomic absorption spectrophotometry method[S]. Beijing: Environmental Sciences Press of China(in Chinese)

[13] National Environmental Protect Bureau of China, National Technology Supervise Bureau of China. 1998. GB17137-1997.Environmental Quality Determination of total chromium-Flame atomic absorption spectrophotometry [S]. Beijing: Environmental Sciences Press of China(in Chinese)

[14] National Environmental Protect Bureau of China, National Technology Supervise Bureau of China. 1998. GB17138-1997.Environmental Quality Determination of Cu and Zn-Flame atomic absorption spectrophotometry [S]. Beijing: Environmental Sciences Press of China(in Chinese)

[15] National Environmental Protect Bureau of China, National Technology Supervise Bureau of China. 1998. GB17139-1997.Environmental Quality Determination of NiFlame atomic absorption spectrophotometry [S]. Beijing: Environmental Sciences Press of China(in Chinese)

[16] National Environmental Protect Bureau of China and National Technology Supervise Bureau of China.1998.GB/T17141-1997.Soil Quality-Determination of Lead and Cadmium: Graphite Furnace Atomic Absorption Spectrophotometry[S]. Beijing: Environmental Sciences Press of China(in Chinese)

[17] National Environmental Protect Bureau of China, 2004. HJ/T 166-2004. The technical specification for soil environmental monitoring[S].Beijing Environmental Sciences Press of China(in Chinese)

[18] Lepeltier C. 1969. A simplified treatment of geochemical data by graphical represatation[J]. Enviromental Geology, 64, 538-550

[19] Liao Zi Ji.1992. Environmental chemistry and biological effects of trace elements[M]. BeiJing. China Environmental Science Press, 178-253

[20] Li Qiang, Mo Dalun.1997. The damage and research progress of As contamination in the soil environment [J]. Tropical and Subtropical Soil Science, 6(4): 291 - 295

[21] Matschullat J., Ottenstein R. and Reimann C. (2000) Geochemical background-can we calculate it[J] Environmental Geology, 39, 990-1000 
[22] Muller G. 1969, Index of geoaccumulation in sediments of the Rhine River[J]. Geojournal, 2(3): 108 118

[23] Salminen R, Tarvainen T, 1997. The problem of defining geochemical baseline. A case study of selected elements and geological materials in Finland. J. Geochemical Exploration, 60(1): 91-98

[24] Salminen R, Gregorauskiene V. 2000. Consideration regarding the definition of a geochemical baseline of elements in the surfical materials in areas differing in basic geology. Applied Geochemistry, 15: 647-653

[25] Sun Chengxing.2002.Red weathering material sources and rare earth elements chemical research in Karst area of Guizhou[D]

[26] Teng Yanguo, Ni Shijun, Tuo Xianguo et al., 2002.Geochemical baseline and trace metal pollution of soil in Panzhihua mining area[J]. Chinese Journal of Geochemistry. 21, 274-281

[27] Teng Yanguo, Tuo Xianguo, Ni Shijun et al., 2003.Environment geochemical of heavy metal contaminants in soil and stream sediment in Panzhihua mining and smelting area, southwestern China[J]. Chinese Journal of Geochemistry, 22, 254-262

[28] Xu Hong-ning, Xu Jia-lin.1996. The cause and the distribution of As abnormal area in China [J]. Soil, 2:80-84

[29] Yi Xiu, Gu Xiaojing, Hou Yanqing, et al., 2010. Assessment on soil heavy metals pollution by Geo-accumulation index in Jinghuiqu irrigation district of Shaanxi province[J]. Journal of Earth Sciences and Environment,32(3):288-291 


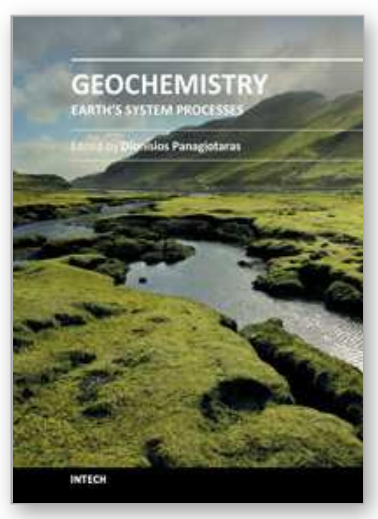

\author{
Geochemistry - Earth's System Processes \\ Edited by Dr. Dionisios Panagiotaras
}

ISBN 978-953-51-0586-2

Hard cover, 500 pages

Publisher InTech

Published online 02, May, 2012

Published in print edition May, 2012

This book brings together the knowledge from a variety of topics within the field of geochemistry. The audience for this book consists of a multitude of scientists such as physicists, geologists, technologists, petroleum engineers, volcanologists, geochemists and government agencies. The topics represented facilitate as establishing a starting point for new ideas and further contributions. An effective management of geological and environmental issues requires the understanding of recent research in minerals, soil, ores, rocks, water, sediments. The use of geostatistical and geochemical methods relies heavily on the extraction of this book. The research presented was carried out by experts and is therefore highly recommended to scientists, underand post-graduate students who want to gain knowledge about the recent developments in geochemistry and benefit from an enhanced understanding of the dynamics of the earth's system processes.

\title{
How to reference
}

In order to correctly reference this scholarly work, feel free to copy and paste the following:

Ji Wang and Yixiu Zhang (2012). Characteristics of Baseline and Analysis of Pollution on the Heavy Metals in Surficial Soil of Guiyang, Geochemistry - Earth's System Processes, Dr. Dionisios Panagiotaras (Ed.), ISBN: 978-953-51-0586-2, InTech, Available from: http://www.intechopen.com/books/geochemistry-earth-s-systemprocesses/characters-of-baseline-and-analysis-of-pollution-on-the-heavy-metals-in-surficial-soil-of-guiyang

\section{INTECH}

open science | open minds

\author{
InTech Europe \\ University Campus STeP Ri \\ Slavka Krautzeka 83/A \\ 51000 Rijeka, Croatia \\ Phone: +385 (51) 770447 \\ Fax: +385 (51) 686166 \\ www.intechopen.com
}

\author{
InTech China \\ Unit 405, Office Block, Hotel Equatorial Shanghai \\ No.65, Yan An Road (West), Shanghai, 200040, China \\ 中国上海市延安西路65号上海国际贵都大饭店办公楼 405 单元 \\ Phone: +86-21-62489820 \\ Fax: +86-21-62489821
}


(C) 2012 The Author(s). Licensee IntechOpen. This is an open access article distributed under the terms of the Creative Commons Attribution 3.0 License, which permits unrestricted use, distribution, and reproduction in any medium, provided the original work is properly cited. 